\title{
Joseph Baker \& Nick Wattie - new insights into the concept of innate talent in sport
}

\author{
CISS Target Article 2019
}

Citation:

Steidl-Müller, L. (2019). Joseph Baker \& Nick Wattie - new insights into the concept of innate talent in sport. Current Issues in Sport Science, 4:107. doi: 10.15203/CISS_2019.107

\section{Editorial}

Steidl-Müller (2019): Joseph Baker \& Nick Wattie - new insights into the concept of

innate talent in sport

CISS_2019.107

\section{Main Article}

Baker \& Wattie (2018): Innate talent in sport: Separating myth from reality

CISS_2018.006

\section{Commentaries}

Davids \& Araújo (2019): Innate Talent in Sport: Beware of an organismic asymmetry comment on Baker \& Wattie CISS_2019.102

Faber (2019): The talent quest - comment on Baker \& Wattie CISS_2019.103

Hambrick \& Burgoyne (2019): Beyond nature vs. nurture in expertise research - comment on Baker \&Wattie CISS_2019.104 Romann, M. (2019): Innate talent is adaptable - comment on Baker \&Wattie CISS_2019.105

Rommers, N. \& Rössler, R. (2019): Innate talent in sport: from theoretical concept to complex reality comment on Baker \& Wattie CISS_2019.106

\section{Response}

Baker \& Wattie (2019): Talent: A contestable, but not contested, concept? Response to commentaries

CISS_2019.108 


\title{
Joseph Baker \& Nick Wattie - new insights into the concept of innate talent in sport
}

\author{
Lisa Steidl-Müller ${ }^{1, *}$ \\ 1 Department of Sport Science, University of Innsbruck, Innsbruck, Austria \\ * Corresponding author: Department of Sport Science, University of Innsbruck, Fürstenweg 185, A-6020 Innsbruck, Austria, \\ Tel: +43 (0) 512-50745904, Fax: +43 (0) 512-50745999 \\ E-Mail: lisa.steidl-mueller@uibk.ac.at
}

\section{TA EDITORIAL}

\section{Article History:}

Published $12^{\text {th }}$ November 2019

Handling Editor:

Lisa Steidl-Müller

University of Innsbruck, Austria

Editor-in-Chief:

Martin Kopp

University of Innsbruck, Austria

\section{ABSTRACT}

In this target article, Joseph Baker and Nick Wattie revisited the review article on the evidence for innate talent published by Howe, Davidson and Sloboda 20 years ago, and focused mainly on whether this concept was reasonable and scientifically sound, and whether the concept of innate talent was valid also in the world of sport. The main article (CISS_3:006) is then discussed by five peer commentaries (CISS_4:102 - CISS_4:106), written by research experts in this field. Finally, Joseph Baker and Nick Wattie provided a closing response (CISS_4:108) acknowledging critiques, suggestions, and extensions brought forward by the commentators.

Citation:

Steidl-Müller, L. (2019). Joseph Baker \& Nick Wattie - new insights into the concept of innate talent in sport. Current Issues in Sport Science, 4:107. doi: 10.15203/CISS_2019.107.

Current Issues in Sport Science (CISS) offers target articles as special features that are published once a year. The editorial board invites well-known research experts of different fields of sport science research to provide an overview of a specific research topic. Researchers of the same field are then invited to write a commentary based on the target article and finally, the authors of the main article respond to the critiques, suggestions, and extensions brought forward by the commentators. We are very proud that two of the most famous researchers in talent research, Joseph Baker and Nick Wattie, provided the third target article dealing with the topic of innate talent in sport (Baker \& Wattie, 2018).

Joseph Baker and Nick Wattie published more than 200 articles and book chapters, among others, most of them dealing with talent research from different perspectives and in different types of sport. Joseph Baker, Professor at the School of Kinesiology and Health Science at York University, did his doctorate at Queen's University about motor learning and skill acquisition and finished it in 2003. He held diverse academic positions as Adjunct Professor, Assistant Professor or Associate Professor at Queen's University, York University, Leeds Metropolitan Univer- sity, Westfälische Wilhelms-Universität Münster, University of Regina, and University of Prince Edward Island. With his numerous research projects conducted, he mainly contributed to a better understanding of talent identification and development, among others. He published a lot of articles also together with Nick Wattie, as for example a proposed conceptualization of talent in sport, recently published in Psychology of Sport and Exercise (Baker et al., 2019). Nick Wattie's PhD thesis dealt with a developmental systems perspective of youth development in sport. Since finishing the PhD in 2011, his research program as postdoctoral research fellow at York University and since 2014 as Assistant Professor at the Ontario Tech University has included multiple areas such as psychosocial and physical health outcomes associated with sport participation, as well as individual and environmental influences on talent identification and development in sport, among others. Both researches belong to the most cited scientists in talent research; thus, we are very proud that they provided a target article on the often discussed issue of innate talent in sport.

The target article consists of the main article written by Joseph Baker and Nick Wattie, five invited commentaries on this article 
by experts in this research field from all over the world (Belgium, Germany, Portugal, Switzerland, United Kingdom, and United States), and a closing response on the commentaries by the authors of the main article.

In 1998, Howe, Davidson and Sloboda, published a review article of the evidence for innate talent in the journal Behavioral and Brain Sciences, which provided 30 commentaries on this target article from leading researchers. This paper has influenced many fields since then and was cited very often. However, much has changed since then, and therefore, Joseph Baker and Nick Wattie (2018) revisited the Howe et al's review dealing with innate talent in sport 20 years later. Their target article ("Innate talent in sport: Separating myth from reality') focused mainly on whether the concept of innate talent was reasonable and scientifically sound, and whether the concept of innate talent was valid also in the world of sport. The authors conclude that, in general, the notion of innate talent appears valid; however, in the world of sport, the utility of innate talent appears to be limited to those working with athletes. No robust indicators of talent currently exist, and a "one size fits all" consensus for talent identification in sports is not possible.

Five international researchers or research groups (Davids \& Araújo, 2019; Faber, 2019; Hambrick \& Burgoyne, 2019; Romann, 2019; Rommers \& Rössler, 2019) provided commentaries with their perspectives on the main article. The main points brought up by these researchers regarding the concept of innate talent were I) the need for better conceptual clarity about the properties of talent in sport, II) better understanding of the real world utility of innate talent in sport, and III) how this field should move forward.

In their response to the commentaries, Wattie and Baker (2019) agree that there is need for a better conceptual clarity about the properties of talent in sport, and that genes influence our development in a dynamic way based on experiences and the opportunities provided by the environment. The authors emphasize that performance in most sports is the result of a complex interaction of variables, and that talent selection processes involve selections between highly skilled athletes and slightly less skilled athletes, which is definitely more challenging than comparing athletes from non-athletes. Due to the complexity of talent as a concept and of navigating potential indicators of talent (Wattie \& Baker, 2019), there are noticeable challenges for future research, but also for practitioners.

Baker and Wattie (2019) concluded their closing response to the commentaries by highlighting the real value of the targetarticle-commentary format for stimulating ideas and debates about important topics. As the topic of talent in sport is a very important one and discussions will go on also in the future, this target article really contributed to a better understanding of the concept of innate talent in sport, even though some issues still remain unclear. We really want to thank Joseph Baker and Nick Wattie for their very interesting article and their clear response to the commentaries. Additionally, a big thank goes also to Keith Davids, Duarte Araújo, Irene Faber, David Z. Hambrick, Alexander P. Burgoyne, Michael Romann, Nikki Rommers, and Roland Rössler for their very interesting and fruitful commentaries on the target article and for putting forward the discussion on the topic of innate talent.

\section{Acknowledgements}

I would like to thank Joseph Baker and Nick Wattie for their very interesting target article as well as all authors for their contributions writing the commentaries.

\section{Funding}

The author has no funding or support to report.

\section{Competing Interests}

The author has declared that no competing interests exist.

\section{Data Availability Statement}

All relevant data are within the paper.

\section{References}

Baker, J., \& Wattie, N. (2018). Innate talent in sport: Separating myth from reality. Current Issues in Sport Science, 3, 006.

Baker, J., Wattie, N., \& Schorer, J. (2019). A proposed conceptualization of talent in sport: The first step in a long and winding road. Psychology of Sport \& Exercise, 43, 27-33.

Davids, K., \& Araújo, D. (2019). Innate Talent in Sport: Beware of an organismic asymmetry - comment on Baker \& Wattie. Current Issues in Sport Science, 4, 102.

Faber, I. (2019). The talent quest - comment on Baker \& Wattie. Current Issues in Sport Science, 4, 103.

Hambrick, D. Z., \& Burgoyne, A. P. (2019). Beyond nature vs. nurture in expertise research - comment on Baker \& Wattie. Current Issues in Sport Science, 4, 104.

Howe, M. J. A., Davidson, J. W., \& Sloboda, J. A. (1998). Innate talents: reality or myth? Behavioral and Brain Sciences, 21, 399-442.

Romann, M. (2019). Innate talent is adaptable - comment on Baker \& Wattie. Current Issues in Sport Science, 4, 105.

Rommers, N., \& Rössler, R. (2019). Innate talent in sport: from theoretical concept to complex reality - comment on Baker \& Wattie. Current Issues in Sport Science, 4, 106.

Wattie, N., \& Baker, J. (2019). Talent: A contestable, but not contested, concept? Response to commentaries. Current Issues in Sport Science, 4, 108. 


\title{
Innate talent in sport: Separating myth from reality
}

\author{
Joseph Baker ${ }^{1, *}$ \& Nick Wattie ${ }^{2}$ \\ 1 Lifespan Health and Performance Laboratory, York University, Toronto, Canada \\ 2 Faculty of Health Sciences, University of Ontario Institute of Technology, Oshawa, Canada \\ * Corresponding author: School of Kinesiology and Health Science, 4700 Keele St., York University, Toronto, Canada, \\ Tel: +1 4167362100 ex 22361, Fax: +1 4167365774 , \\ Email: bakerj@yorku.ca
}

\section{COMMENTARY}

\section{Article History:}

Submitted $6^{\text {th }}$ November 2017

Accepted $9^{\text {th }}$ March 2018

Published $3^{\text {rd }}$ May 2018

Guest Editor:

Lisa Steidl-Müller,

University of Innsbruck, Austria

Editor-in-Chief:

Martin Kopp

University of Innsbruck, Austria

\begin{abstract}
Twenty years ago, Howe, Davidson and Sloboda (1998) provided a state of the science review of innate talent. This paper was extremely influential although much has changed in the two decades since it was published. In this review, we revisit Howe et al's assessment and discuss current research on innate talent in sport, a domain that was largely ignored in the original review. After re-evaluating Howe et al's criteria for innate talent we conclude that with the exception of criterion 5 (i.e., talent is domain specific), these criteria are still useful in the context of existing evidence in sport. We subsequently examine two complementary issues: Is the concept of innate talent valid? Does the concept have any utility? We conclude the concept of innate talent is valid but currently has limited utility to those working in high performance sport. We highlight several areas of future research that will ultimately inform the value of innate talent to those working at the frontlines of athlete development.
\end{abstract}

Keywords:

Nature-nurture - athlete - development - giftedness - expertise

Citation:

Baker, J. \& Wattie, N. (2018). Innate talent in sport: Separating myth from reality. Current Issues in Sport Science, 3:006. doi: 10.15203/CISS_2018.006

The possibility that a person's ultimate achievement might lie in qualities transmitted at birth has dominated discussions for over two thousand years. In ancient Greece, Plato argued for a largely nature-focused view where all knowledge was present at birth (Cowie, 1999). The first scientific exploration of these varying influences can be traced to the work of Francis Galton and his book Hereditary Genius (Galton, 1869). This text formed the basis for more systematic examinations of concepts like talent, giftedness, and genius. Twenty years ago, Howe, Davidson and Sloboda wrote a seminal review of the evidence for innate talent in the journal Behavioral and Brain Sciences. This paper was extremely influential to many fields (citation counts as of September 2017 are 741 times on Google Scholar and 303 times on Psychlnfo). In addition to a very extensive and thoughtful review, the journal provided 30 pointed commentaries from leading researchers that followed the target article. Much has changed in the field of talent science since 1998. Perhaps most significantly, the Howe et al. paper was written before the human genome was mapped in 2001, a development that has revolutionized most fields of science (e.g., medi- cal genetics, genomics, proteomics). In this field, sport science, talent continues to be a dominant topic (see Baker, Cobley, Schorer, \& Wattie, 2017). Questions like, What is talent? Can we make accurate decisions about who is likely to succeed? continue to preoccupy sport scientist and practitioners alike. In the sections that follow, we revisit Howe et al.'s review as it relates specifically to the domain of sport, a domain where talent and its early identification/selection/development remain a cornerstone of what sport science is and a domain that was largely ignored in the original review. We provide a state of the science review based on existing evidence from sport and borrowing from other areas of science where appropriate. Importantly, we have retained the vital discussions that come from targeted commentaries from leading scientists in this field followed by a short discussion of any issues raised in the commentaries.

\section{Defining Innate Talent}

In their original treatise, Howe et al. (1998; pp. 399-400) set up five criteria for their definition of innate talent: 
1) It originated in genetically transmitted structures and hence is at least partly innate.

2) The full effects may not be evidenced at an early stage, but there will be some advance indications, allowing trained people to identify the presence of talent before exceptional levels of mature performance have been demonstrated.

3) These early indications of talent provide a basis for predicting who is likely to excel.

4) Only a minority are talented, for if all children were, there would be no way to predict or explain differential success. Finally,

5) talents are relatively domain-specific.

This definition is somewhat controversial; others have proposed different conceptualizations of what talent is and what this variable means for high performance sport, most notably Gagné's Differential Model of Giftedness and Talent, which has been used in several studies from researchers based at the Australian Institute of Sport (e.g., Gulbin, Oldenziel, Weissensteiner, \& Gagné, 2010). Moreover, talent is conceptually distinct from expertise, which is defined as superior or exceptional performance compared to others in a domain (for further discussion see Baker, Schorer, \& Wattie, 2015). However, the multi-faceted definition provided by Howe et al. was a reasonable basis for examining the evidence at the time. If we re-evaluate these five criteria, some still seem strongly supported while others need to be re-considered. In the next section we consider each criterion relative to the domain of sport.

\section{Criterion 1 - Innate talent is, at least partly, genetically transmitted}

By its very definition, innate talent must have some element of 'innateness' (i.e., a quality that is inborn or natural) and our use of this adjective is quite purposeful, distinguishing this concept from other descriptions of talent such as Gagné's, where it is seen as representing "outstanding systematically developed skills" (Gagné, 2004; p. 119). Perhaps one of the most considerable changes since the 1998 review has been the rapid advancement of the field of sport genetics. Starting in 2001, sport geneticists have published an annual (sometimes biennial) 'Gene Map' of genetic factors affecting performance and health-related fitness (e.g., the most recent iteration is Sarzynski et al., 2016). Collectively, this field of research is grounded in the assumption that genetic factors affect exercise, fitness and performance phenotypes (and vice versa).

Criteria 2-3 - Talent will have some advanced indications and those with training can predict those with greater likelihood of success.

One of the important themes that we will re-visit in this discussion is the relationship between theory and practice. Howe et al.'s second and third criteria are good examples of why this relationship is important to discussions of innate talent in sport. In a later section we discuss the evidence for the efficacy of advanced indicators for predicting later success. However, regardless of whether there is a strong theoretical or empirical rationale for innate talent, we would argue that coaching practice in high performance sport systems is consistent with criteria two and three. Sports may vary in their structure, policies and implementation, but the practice of attempting to identify talent and predict who has a greater chance of success (however defined) is common (Vaeyans, Lenoir, Williams, \& Phillippaerts, 2008). This happens every time a coach makes the decision to select a young athlete to a competitive team or relegate them to recreational streams of participation. It also happens when scouts or coaches make decisions about who to offer athletic scholarships to at the college / university level, during recruitment to high performance youth academies (such as in soccer), and during entry drafts to elite amateur developmental leagues or professional sports teams. In particular, the identification and selection of very young athletes into more competitive/higher performance streams in order to accelerate athlete development (Vaeyans et al., 2008) presents a compelling example that criteria two and three are ubiquitous throughout sport. This identification can occur as young as six years of age, prior to when athletes have had the chance to acquire a meaningful amount of deliberate practice (Baker \& Young, 2014; Ericsson, Krampe \& Tesch-Römer, 1993). Indeed, as we were writing this review, the University of Hawaii offered an 11-year-old boy (an American Football Quarterback) an athletic scholarship (VanHaaren, 2017). Howe et al. (1998) asserted that it was important to explore the validity of the talent account because "researchers as well as educators rely on the talent account" (p. 400). We agree, and would add that in sport the predominant policies and structure of youth sport systems also reflect the talent account to a certain extent. In this case, the 'medium is part of the message'; the fact that ability streaming at very young ages is built into the structure of many youth sports embodies messages about innate talent (independent of a practitioner's belief). Therefore, by virtue of its ubiquity and the reliance on this account of talent in real world practices, this point still has relevance today, perhaps independent of the empirical support.

\section{Criterion 4 - Only a minority are talented}

At the outset of Howe et al.'s paper they summarized a number of different concepts and terms related to innate talent. These included "unusual excellence", "special ability", "possessed innately", "aptitude", "giftedness", and of course "innate talent". Explicitly or implicitly these terms suggest only a minority are talented, which is congruent with accounts of talent in sport. This criterion seems necessary at a logistical level (although we will discuss the biological basis for this premise in a later section). In sport, this refers to a small 'end-group' (i.e., teams and leagues at the highest level), with limited positions available. Moreover, even at the highest levels of sport there is evident variability in skill/capability between athletes. Indeed, this variability is cel- 
ebrated via All-Star teams, myriad awards (e.g., Most Valuable Player, Ballon D'Or), and Hall of Fame inductions. Only a very small minority receives such accolades and acknowledgment for the special and unique level of ability (e.g., between $1 \%$ and $4 \%$ of professional athletes in the National Hockey League and Major League Baseball; Baker et al., 2015). Acknowledgment of 'talent' implies an increasingly exclusionary hierarchy. Again, independent of whether a person believes in innate talent, in a practical sense significant variation in skill and performance exists in sport (although some paradigms view talent existing within everyone: see Dries, 2013).

\section{Criterion 5 - Talent is relatively domain specific.}

In their review, Howe et al. emphasized that talent in a domain may result from different combinations of different skills, but, that notwithstanding, talents are relatively domain-specific ( $p$. 400). However, on further reflection, the notion that talent is domain specific may be unreasonable. The idea that expertise is domain specific is relatively uncontroversial (e.g., see Loffing, Schorer, Hagemann, \& Baker, 2012); however, the notion that humans would have an innate quality that would be specific to a single domain of endeavor does not seem to fit with biological parsimony. Nature is nothing if not thrifty. Therefore, if talent exists, it is more likely that it starts as a capacity that could predispose an individual to related domains (e.g., a genetic propensity to have a high proportion of fast twitch muscle fibers would predispose an athlete to many anaerobically-based sports) and that over time and through training, this general capacity adapts to become domain specific (see Simonton, 2017). ${ }^{1}$

The Howe et al. criteria were reasonable for conceptualizing their discussion of talent and our intention is not to re-examine each of these here, although discussions of innate talent invariably touch on these factors. Instead, we focus on providing clear conclusions on this issue for those working in the domain of sport. More specifically, we use sport-related evidence to justify two main conclusions. The first is that from a theoretical and conceptual perspective the notion of talent is reasonable. The second conclusion is that, at present, the concept of talent has very limited utility to the world of sport.

\section{The concept of innate talent is valid}

For the purpose of this discussion, we put aside dichotomized arguments about nature versus nurture. We have explored issues related to dichotomized and deterministic conceptualizations of nature versus nurture elsewhere (see Davids, \& Baker, 2007; Wattie \& Baker, 2017), as have others (Klissouras, 2001; Singer, \& Janelle, 1999). Similarly, while discussions about

1 Incidentally, at face value this feature is also congruent with the principle behind 'talent transfer' initiatives (see Rea \& Lavallee, 2017). whether innate talent is necessary and/or sufficient to explain expert sport performance often arise (i.e., arguments about degrees of importance, see Tucker, \& Collins, 2012), in this section we focus on whether the concept of innate talent is reasonable from a theoretical perspective. Importantly, the premise of innate talent as a concept does not have to rely on a dichotomized or deterministic conceptualization (i.e., that innate talent is the sole determinant of sport expertise), but rather, there may be evidence supporting varying degrees of innate talent, where talent exists on a continuum.

The eminent geneticist and evolutionary biologist Theodosius Dobzhansky once remarked that 'Nothing in biology makes sense except in the light of evolution' (Dobzhansky, 1973). Indeed, evolution by natural selection has become such a dominant framework that most scientists agree that all biological phenomena (including discussions of innate talent) must fit with evolutionary principles. With regard to innate talent, a consequence of the genetic variation between individuals is that they can differ substantially from the population average on any number of characteristics. When individual characteristics favorably align with the specific requirements of a sport task (Davids, \& Baker, 2007; Newell, 1986), this may reflect some level of 'innate talent' in the same way a genetic predisposition to be extremely tall may reflect an innate propensity for sports where height is an advantage. An evolutionary probabilistic standpoint assumes there is a distribution of ability and/or individual characteristics (i.e., degrees of talent) across a population with very small numbers of individuals at the very highest and lowest levels. In this paradigm, differences in innate predispositions are somewhat inevitable.

As many sports have matured, competition intensity and positional-specificity has increased. As a result, athletes' bodies have become more distinct from the general population and unique in accordance with the characteristics that probabilistically confer performance advantages in their sport. This has been referred to as the "expanding universe of athletic bodies" (p. 763, Norton, \& Olds, 2001): the shift away from the notion of the 'ideal average body' toward niche bodies for specific sports and/or positions within sport. In many sports, athletes have increased in height and mass, and in those sports larger athletes may experience greater success (e.g., longer careers and greater economic rewards: Norton, \& Olds, 2001). Moreover, these secular changes in morphology have outstripped any changes in the general population (see Norton, \& Olds, 2001; Olds, 2001). For example, Norton, and Olds (2001) quantified this effect by calculating the "degree of superimposition of the frequency distributions" (p. 764) between the general population and elite athlete populations (age and sex matched). Their analyses suggest that there is a less than a $1 \%$ chance (i.e., 0.001) of finding someone with the size (height and mass) needed to be a lineman in the National Football League (from the general population of 20-29 year old males in the United States in the 1990s). Similarly, Norton, and Olds' (2001) analyses for National Basketball Association (NBA) players suggest a 5\% chance of finding someone from the general population with 
the size needed to play in the NBA (this statistics does not account for positional differences).

Importantly, characteristics like height are thought to be highly constrained by genetics, with most estimates suggesting that up to $80 \%$ of height is explained by genetic factors (McEvoy, $\&$ Visscher, 2009). Moreover, studies have suggested genetic origins for capacities related to strength, aerobic capacity and responsiveness to training (Bouchard et al., 1998; Bouchard et al., 1999; Calvo et al., 2002; Rankinen et al., 2006), and injury susceptibility (e.g., traumatic brain injury: Bennett, Reuter-Rice, \& Laskowitz, 2016). The naturally occurring coordination patterns of some youth may also favourably align with the task constraints of specific sports (Chow, Davids, Button, \& Renshaw, 2016; Davids, Button, \& Bennett, 2008; Glazier, 2017), which may provide performance advantages and be construed as innate talent by practitioners. While a single gene explanation for genetic influences on sport performance is highly unlikely (see Davids, \& Baker, 2007), these findings suggest genetic (or epigenetic) origins to predispositions for specific sport domains, and therefore the existence of different degrees of innate talent.

There are four important points that emerge from these secular trends and research on inter-individual differences in capacity, which align with the criterion of talent. First, which is relatively uncontroversial, is that anthropometrics and physiological capacity are important (some might say essential) to athlete development and success. The relationship between size and physical maturity with development performance has been well documented (see Malina, Cumming, Coelho e Silva, \& Figueiredo, 2017), and task constraints within certain sports (e.g., the height of the net in basketball or the aerobic demands of cycling) favourably interact with individual-level characteristics. In some relatively 'closed' sports (e.g., diving, gymnastics), anthropometric and physiological characteristics might be a relatively greater constraint than more open sports. Second, there appears to be at least a partial genetic component to these underlying characteristics and capacities (see above). Third, by virtue of how uncommon the heights, masses, or physiological capacities of elite athletes are compared to the general population, these 'talents' are rare (Criterion 4). Last, such factors are consistent with individuals being predisposed to certain domains (see discussion of Criterion 5 above).

Conversely, talent cannot be reduced to relatively simple discrete measures like size, strength, speed, or aerobic capacity (see Abbott, Button, Pepping, \& Collins, 2005). Instead, talent should be conceptualized as a multidimensional construct that cannot be aggregated to a single score and is comprised from different combinations of different abilities (Baker, Schorer, \& Wattie, 2018). Indeed, a recent systematic review highlighted the particular utility of multidimensional approaches to talent identification (Johnston, Wattie, Schorer, \& Baker, 2018). However, evolutionary or probabilistic accounts still allow for the confluence of different characteristics.

In addition to the theoretical and probabilistic arguments for the existence of innate talent, there are intuitive accounts from practitioners (e.g., coaches and scouts): 'I know it when I see $i t$ ', or 'they just have it'. Often such claims emerge from the exceptional early performance of young athletes. These accounts could be dismissed as anecdotal and/or selective attention given retrospectively to only the instances of successful talent identification. Conversely, perhaps anecdotes from experienced practitioners should be given more credence in discusses of rare outcomes, like innate talent, than they generally do in scientific discussion. Moreover, in this context it may be worth discussing whether notions such as statistical significance and power are ecologically valid when considering the identification of a necessarily small, exceptional sample.

While talent is nebulous, hard to define and to observe, there are signs that it exists via proxies and theory. From our perspective, there is sufficient, yet indirect, evidence to support its existence, even though its existence at present is largely theoretical. Therefore, it is incumbent upon researchers and practitioners to refine our understanding of that concept and to test its falsifiability. We conclude that based on the available evidence, innate talent as a theoretical construct is defensible. However, the distinction between whether it makes sense as a theoretical concept versus as an applied (or practical) concept is important.

\section{Current conceptualizations of talent have limited utility in the 'real world'}

In the section above we conclude that there is a theoretical and conceptual rationale for the notion that individuals differ on qualities that might have some relevance for performance in specific tasks. This is a long way, however, from concluding innate talent is a useful concept for athletes, coaches, parents and administrators. In order to have 'real world' utility, talent needs to be measureable using valid and reliable tools. In the following section we examine evidence for the existence of these indicators.

The notion that there may be early indicators of future elite sport performance is a cornerstone of sport science, and has been since the earliest phases of the field. In the 1950s and 1960s, sport researchers explored general capacities that might explain how certain people succeed in athletic tasks (following on the notion of Spearman's G, developed to represent a general quality of intelligence, Spearman, 1904). One example is the concept of the generalized motor ability, which is built on the notion that a) individual motor skills are related to one another, b) a single global ability underpins each ability, and c) people are capable of performing all motor skills at similar levels. A similar concept, motor educability, refers to the general ability to learn motor skills (i.e., those with high motor educability more easily learn motor tasks, see for example, Gire, \& Espenschade, 1942; Gross, Griessel, \& Stull, 1956; McCloy, 1937). Although there was considerable research exploring these concepts, the evidence for them is not strong (see, for example, Drowatzky, \& Zuccato, 1967). While the search for general tests of motor coordination 
that might inform talent detection has seen renewed interest in recent years (see Faber et al., 2014; Vandorpe et al., 2012), the attention to 'sport genetics' has dominated many contemporary discourses.

Over the past two decades, the field of sport genetics has expanded considerably. The identification of specific genes, whose presence might be used to predict whether someone is more likely to succeed in a given domain, would arguably reflect a critical marker of innate talent. During this period, genetic research has noted several intriguing findings that might relate to the concept of innate talent. For instance, early studies highlighted the gene for Angiotensin Converting Enzyme $(A C E)$, which influences blood pressure and fluid-electrolyte balance. Initial examinations of endurance athletes ranging from Olympic rowers (Gayagay et al., 1998) to Ironman triathletes (Collins et al., 2004) suggested this gene might be important in endurance tasks. Similarly, research on other genes including COL5A1 (e.g., Collins, Mokone, September, van der Merwe, \& Schwellnus, 2009; Mokone, Schwellnus, Noakes, \& Collins, 2006) and Alpha Actin 3 (MacArthur, \& North, 2004) has supported the notion that the presence or absence of certain genes may predict athletes from non-athletes. It is important to note that predicting athletes from non-athletes is appreciably easier than predicting who among a group of athletes has greater potential.

In addition to these explorations of genetic markers, recent discussions of talent development have considered predicting talent from indicators of long-term engagement. The basis of this argument comes from the extensive period of training that seems to be required for expertise (Baker, \& Young, 2014). If one is able to predict who is more likely to meaningfully engage in intensive training for several years then this might reflect a proxy of innate talent. For example, an athlete's ability to regulate their own learning is emerging as a key variable distinguishing elite performers from those of lower levels of skill (Toering, Elferink-Gemser, Jordet, \& Visscher, 2009) and researchers have begun to explore the relationship between self-regulatory processes and practice behaviors in sport (Elferink-Gemser et al., 2015; Tedesqui, \& Young, 2015). Similarly, studies have noted the relevance of personality variables such as self-control and grit to elite athlete development (Tedesqui, \& Young, 2017a, 2017b). Better understanding of how these variables change over time and how they interact with training and other environment and genetic factors will improve our ability to identify those with the greatest potential for future success.

One of the concerns with the genetic studies noted above is that the work in this area is still emerging and considerable replication and extension is required before these findings will have the robust validity necessary to make conclusions about their importance. While these areas of research are promising, genetic researchers warn against their use in talent identification settings - at least given our current understanding (see Loland, 2015; Vlahovich, Fricker, Brown, \& Hughes, 2017; Webborn et al., 2015). However, it is important to note this does not mean we have sufficient evidence to dismiss the concept of innate talent that might one day be recognizable through direct-to-consumer genetic tests. The absence of evidence is not evidence of absence. As technologies and methods improve and our ability to capture the complex interactions between genetics and environment increases, our capacity to identify qualities that predict future outcomes (e.g., behaviour, attainment) should improve. Nevertheless, the utility of innate talent to those working with athletes as coaches, trainers and administrators currently appears to be limited.

\section{Key Issues in Future Work}

Having set out our conclusions regarding talent, at least as it is currently understood, we conclude with a discussion of key areas for researchers to consider in future work.

\section{Measurement}

One of the challenges of bridging gaps between talent as a concept and the actual utility of that concept in applied contexts relates to measurement. First and foremost, many attempts to identify talent rely on the measurement of discrete and unstable characteristics (Abbott et al., 2005). These characteristics also tend to be predominantly physical measures (Johnston et al., 2018) that can directly influence an athletes' performance on a range of tasks than can underpin sport performance more broadly (e.g., speed and strength). However, performance does not necessarily equal talent, as demonstrated by the poor correlation between current performance and future performance (Baker et al., 2017). Moreover, inherent to unstable characteristics is their non-linearity (e.g., inter-individual differences and intra-individual differences in growth and maturation), which can increase the likelihood of both Type I and II errors when relied upon too heavily.

Another challenge to reconciling the concept of innate talent with its real world utility is whether or not it is sufficient to measure talent indirectly, or if it is necessary to measure it directly. For example, can measurement of the expression of talent be enough to count as 'measuring talent'; the expression of talent often being performance. Whether or not it is sufficient to measure talent directly or indirectly likely also relates to one's definition of talent. However, as a matter of necessity, this is an issue that might have to be resolved, or at least the implications of which better understood, until our measurement technologies and understanding of genetics and gene-environment interaction increases.

\section{Replication}

The world of high performance sport moves rapidly, much more rapidly than the scientific peer-review process. As a result, coaches, athletes and administrators are often quick to embrace new findings in an effort to obtain a competitive advantage over their opponents. However, this can result in aimless trips 'down the rabbit hole' before the reliability and validity to 
these findings has been established. It is important to note that much of this emerging work requires considerable additional research replicating novel results and determining the extent to which they are generalizable to athlete populations en masse. One recent example of this is the landmark Great British Olympians project (Hardy et al., 2017), which sought to understand the developmental differences between athletes who won multiple medals at major championships and a matched group of high performance athletes who did not achieve the same level of success. This study, and a host of others in this area (e.g., Baker et al., 2003; Ward, Hodges, Starkes, \& Williams, 2007), relied on retrospective recall of athletes in identifying key factors (e.g., life and training histories, etc.) that may have promoted superior development in some groups over others. It is critical to remember that sport systems are constantly in flux, evolving as political and social desires change. As a result, retrospective and longitudinal studies may adequately explain the antecedents of optimal development for athletes who competed in the past but arguably have limited relevance for athletes outside this generation.

\section{Extension}

In a recent systematic review, Johnston et al (2018) lamented the clear lack of systematic, longitudinal work in the field of talent in sport. They highlighted the need to extend our conceptualizations of talent and its development to more appropriately model the complex and interactive effects of environment and genetics. The majority of past research has focused on physical and anthropometric variables, arguably because they are the easiest to objectively measure. However, in most sports, predicting future performance can be startlingly complex and is never entirely determined by one class of variables. Most approaches to athlete development, by researchers and practitioners alike, tend to focus on the identification of a single approach or model to explain this development process when there could be varying pathways to get to the same endpoint. For example, one athlete may have a superior genotype for a desirable anthropometric profile and as a result becomes a player who uses her height/body as the advantage while a second athlete, who does not have these anthropometric advantages, develops superior decision-making and play-reading skills.

\section{Implications}

If the constituent components of talent (i.e., talent characteristics) exist on a continuum, from none or very little to a high degree, then there may be a need to evaluate how we deal with components of talent. First, talent may need to be considered as a multidimensional construct that can be composed of different permutations and combinations of characteristics and abilities (see Baker et al., 2018). Cluster analyses and methods that consider the composition of multiple variables may be particularly useful going forward, and such methods may increase the utility of talent identification measures. Second, the continuum conceptualization of innate talent implies that there is likely an acceptable range of values for specific characteristic and/or ability, and that ranges along continuums are outside the realistic threshold to be considered 'talented' in a specific domain. The challenge is that thresholds are obviously difficult to assess during youth and adolescent development, and would themselves have to be dynamic. Once we have a better understanding of the probability estimates for measures of talent and/or performance, then more accurate threshold for athlete selection can be prescribed. Last, if we conceptualize talent along continuums with probability estimates, then we need methods that match this conceptualization. Bayesian inference (see Bayarri, \& Berger, 2004; Eddy, 2004), and the use of dynamic and flexible prior probabilities to inform likelihood estimates, may be a useful direction going forward. This would also allow practitioners to better understand the implications of evidence about talent (e.g., that it is probabilistic not deterministic; that inefficient systems have higher levels of Type I and II errors).

Another implication for our position could be that in lieu of good measures of innate talent, practitioners should focus exclusively (or nearly exclusively) on the environment, specifically deliberate practice (Baker \& Young, 2014; Ericsson et al., 1993). Some practitioners undoubtedly already do this, and a number of popular books advocate this approach to athlete development (e.g., Syed, 2010). This would certainly be an unintended consequence of our argumentation. We have argued elsewhere that this type of deterministic approach, and the message that deliberate practice is sufficient to explain different levels of achievement, can be harmful (Wattie \& Baker, 2017). Moreover, simplistic views such as those expounding that a single factor (e.g., genetics or deliberate practice) run the risk of being over-parsimonious to the point of obfuscation. Consider this thought exercise: Imagine a sport and context where there is considerable popularity for deliberate practice among practitioners and parents. Youth participation is professionalized from young ages, and young athletes have to engage in similarly structured deliberate practice. Perhaps coaches even strictly monitor and mandate the same amounts of deliberate practice for each athlete. Would such a context, where differences in the environment are effectively eliminated, actually serve to increase the influence of innate biological difference in athlete development? Unless proponents of this deterministic environmentalism in our thought exercise are willing to assert that all athletes will experience exactly the same developmental outcomes, then some differences between athletes would have to be the result of innate biological differences (e.g., due to injury risk, responsiveness to training, rates of learning, or anthropometric advantages). The world in our thought experiment is undoubtedly an over-simplification, and is a bit facetious. Nevertheless, versions of this example could be an unintended consequence of not considering the theoretical plausibility for the existence of innate talent; regardless of whether we can accurately measure innate talent. 


\section{Concluding Thoughts}

Our intentions with this review were to celebrate the contribution of Howe et al. 20 years ago and highlight how innate talent is conceptualized and applied in the field of sport science. Based on existing theoretical and empirical evidence, the notion of innate talent appears valid given key theoretical principles that govern the sciences underpinning sport science (e.g., biological diversity, natural selection as a mechanisms of continued species evolution). However, the theoretical principles that support the existence of innate talent also stipulate that it exists along a continuum and that it is necessary but not sufficient to explain exceptional performance. As such, any understanding of innate talent cannot be divorced from the necessity to understand the complete ecology of the developmental environment.

However, in order to have any utility in the training environment, talent (whatever it is) needs to be measurable and with the exception of a few variables related to body size, no robust indicators of talent currently exist. Moreover, examinations of long-term predictions indicate very poor accuracy in talent selection decisions suggesting that sport systems grounded in early identification of talent may do more harm than good, although the size of the effects are largely unknown due to a lack of research in this area. The 20 years since Howe et al's review have seen rapid and meaningful advancement in our understanding of talent in sport but this understanding is far from complete. Continued evaluation and discussion will ultimately determine the value and cost of this concept in sports systems that are currently underpinned by early selection of athletes into more and more specialized pathways.

\section{Funding}

This work was supported in part by grants from the Social Sciences and Humanities Research Council of Canada (430-201500904, 862-2014-0001, 435-2017-1398)

\section{Competing Interests}

The authors have declared that no competing interests exist.

\section{Data Availability Statement}

All relevant data are within the paper.

\section{References}

Abbott, A., Button, C., Pepping, G.-J., \& Collins, D. (2005). Unnatural selection: Talent identification and development in sport. Nonlinear Dynamics, Psychology, and Life Sciences, 9, 61-88.

Baker, J., Cobley, S., Schorer, J., \&Wattie, N. (2017). The Routledge handbook of talent identification and development in sport. London: Routledge.

Baker, J., Schorer, J., \& Wattie, N. (2015). Defining expertise: A taxonomy for researchers in skill acquisition and expertise. In J. Baker and D. Farrow (Eds.), Routledge Handbook of Sport Expertise (pp. 145-155). London: Routledge.

Baker, J., Côté, J., \& Abernethy, B. (2003). Sport specific training, deliberate practice and the development of expertise in team ball sports. Journal of Applied Sport Psychology, 15, 12-25.

Baker, J., Schorer, J., \& Wattie, N. (2018). Compromising talent: Issues in identifying and selecting talent in sport. Quest, 70, 48-63.

Baker, J. \& Young, B. W. (2014). 20 years later: Deliberate practice and the development of expertise in sport. International Review of Sport \& Exercise Psychology, 7, 135-157.

Bayarri, M. J., \& Berger, J. O. (2004). The interplay of Bayesian and frequentist analysis. Statistical Science, 19, 58-80.

Bennett, E. R., Reuter-Rice, K., \& Laskowitz, D. T. (2016). Genetic influences in traumatic brain injury. In D. Laskowitz \& G. Grant (Eds.), Translational research in traumatic brain injury. Boca Raton, USA: CRC Press.

Bouchard, C., An, P., Rice, T., Skinner, J. S., Wilmore, J. H., Gagnon, J. et al. (1999). Familial aggregation of VO2max response to exercise training: results from the HERITAGE family study, Journal of Applied Physiology, 87, 1003-1008.

Bouchard, C., Daw, W., Rice, T., Perusse, L., Gagnon, J., Province, M. A. et al. (1998) Familial resemblance for VO2max in the sedentary state: the HERITAGE family study, Medicine \& Science in Sports and Exercise, 30, 252-258.

Calvo, M., Rodas, G., Vallejo, M., Estruch, A., Arcas, A., Javierre, C., Viscor, G. \& Ventura, J. (2002). Heritability of explosive power and anaerobic capacity in humans. European Journal of Applied Physiology, 86, 218-225.

Chow, J. Y., Davids, K., Button, C., \& Renshaw, I. (2016). Nonlinear pedagogy in skill acquisition: An introduction. London: Routledge.

Collins, M., Mokone, G. G., September, A. V., van der Merwe, L., \& Schwellnus, M. P. (2009). The COL5A1 genotype is associated with range of motion measurements. Scandinavian Journal of Medicine and Science in Sports, 19, 803-810.

Cowie, F. (1999). What's within? Nativism reconsidered. Oxford: Oxford University Press.

Davids, K., \& Baker, J. (2007). Genes, environment and sport performance: Why the nature-nurture dualism is no longer relevant. Sports Medicine, 37, 961-980. 
Davids, K., Button, C., \& Bennett, S. J. (2008). Dynamics of skill acquisition: A constraints-led approach. Champaign, IL: Human Kinetics.

Dobzhansky, T. (1973). Nothing in biology makes sense except in the light of evolution. American Biology Teacher, 35, 125129.

Dries, N. (2013). The psychology of talent management: A review and research agenda. Human Resource Management Review, 23, 272-285.

Drowatzky, J. N., \& Zuccato, F. C. (1967). Interrelationships between selected measures of static and dynamic balance. Research Quarterly, 38, 509-510.

Eddy, S. R. (2004). What is Bayesian statistics? Nature: Biotechnology, 22, 1177-1178.

Elferink-Gemser, M. T., De Roos, I., Torenbeek, M., Fokkema, T., Jonker, L., \& Visscher, C. (2015). The importance of psychological constructs for training volume and performance improvement: a structural equation model for youth speed skaters. International Journal of Sport Psychology, 46, 726744.

Ericsson, K. A., Krampe, R. T., and Tesch-Römer, C. (1993). The role of deliberate practice in the acquisition of expert performance. Psychological Review, 100, 363-406.

Faber, I. R., Oosterveld, F. G., \& Nijhuis-Van der Sanden, M. W. (2014). Does an eye-hand coordination test have added value as part of talent identification in table tennis? A validity and reproducibility study. PloS One, 9, e85657.

Gagné, F. (2004). Transforming gifts into talents: The DMGT as a developmental theory. High Ability Studies, 15, 119-147.

Galton, F. (1869). Hereditary genius. London: Macmillan.

Gayagay, G., Yu, B., Hambly, B., Boston, T., Hahn, A., Celermajer, D. S., \& Trent, R. J. (1998). Elite endurance athletes and the ACE I allele - the role of genes in athletic performance. Human Genetics, 103, 48-50.

Gire, E., \& Espenschade, A. (1942). The relationship between measures of motor educability and learning specific motor skills. Research Quarterly, 13, 43-56.

Glazier, P. (2017). Could sports biomechanics provide the missing pieces to the talent identification and development puzzle? In J. Baker, S. Cobley, S. Schorer, \& N. Wattie (Eds.), The Routledge handbook of talent identification and development in sport (pp.234-247). London: Routledge.

Gross, E., Griessel, D. C., \& Stull, G. A. (1956). Relationship between two motor educability tests, a strength test, and wrestling ability after eight weeks of instruction. Research Quarterly, 27, 395-402.

Gulbin, J., Oldenziel, K., Weissensteiner, J. \& Gagné, F. (2010). A look through the rear view mirror: Developmental experiences and insights of high performance athletes. Talent Development and Excellence, 2, 149-164.

Hardy, L., Barlow, M., Evans, L., Rees, T., Woodman, T., \& Warr, C. (2017). Great British medalists: Psychosocial biographies of super-elite and elite athletes from Olympic sports. Progress in Brain Research, 232, 1-119.
Howe, M. J. A., Davidson, J. W., \& Sloboda, J. A. (1998). Innate talents: reality or myth? Behavioral and Brain Sciences, 21, 399-442.

Johnston, K., Wattie, N., Schorer, J., \& Baker, J. (2018). Talent identification in sport: A systematic review. Sports Medicine, 48, 97-109.

Klissouras, V. (2001). The nature and nurture of human performance. European Journal of Sport Science, 1, 1-10.

Loffing, F., Schorer, J., Hagemann, N., \& Baker, J. (2012). On the advantage of being left-handed in volleyball: Further evidence of the specificity of skilled visual perception. Attention, Perception and Psychophysics, 74, 446-453.

Loland, S. (2015). Against genetic tests for athletic talent: The primacy of the phenotype. Sports Medicine, 45, 1229-1233.

MacArthur, D. G., \& North, K. N. (2004). A gene for speed? The evolution and function of alpha-actinin-3. Bioessays, 26, 786-795.

Malina, R. M., Cumming, S. P., Coelho e Silva, M. J., \& Figueiredo, A. J. (2017). Talent identification and development in the context of 'growing up'. In J. Baker, S. Cobley, J. Schorer, J., \& N. Wattie (Eds.). The Routledge handbook of talent identification and development in sport (pp. 148-166). London: Routledge.

McCloy, C. H. (1937). An analytic study of the stunt type tests as a measure of motor educability. Research Quarterly, 8, 46-55.

McEvoy, B. P., \& Visscher, P. M. (2009). Genetics of human height. Economics \& Human Biology, 7, 294-306.

Mokone, G. G., Schwellnus, M. P., Noakes, T. D., \& Collins, M. (2006). The COL5A1 gene and Achilles tendon pathology. Scandinavian Journal of Medicine and Science in Sports, 16, 19-26.

Newell, K. M. (1986). Constraints on the development of coordination. In M. G. Wade, \& H. T. A. Whiting (Eds.), Motor development in children: Aspects of coordination and control (pp. 341-361). Amsterdam: Martin Nijhoff.

Norton, K., \& Olds, T. (2001). Morphological evolution of athletes over the 20th century: Causes and consequences. Sports Medicine, 31, 763-783.

Olds, T. (2001). The evolution of physique in male rugby union players in the twentieth century. Journal of Sports Sciences, 19, 253-262.

Rankinen, T., Bray, M. S., Hagberg, J. M., Pérusse, L., Roth, S. M., Wolfarth, B., \& Bouchard, C. (2006). The human gene map for performance and health-related fitness phenotypes: the 2005 update. Medicine \& Science in Sports \& Exercise, 38, 1863-1888.

Sarzynski, M. A., Loos, R. J., Lucia, A., Pérusse, L., Roth, S. M., Wolfarth, B., Rankinen, T., \& Bouchard, C. (2016). Advances in exercise, fitness and performance genomics in 2015. Medicine and Science in Sports and Exercise, 48, 1906-1916.

Simonton, D.K. (2017). Does talent exist? Yes! In J. Baker, S. Cobley, J. Schorer and N. Wattie (Eds.) Routledge handbook of talent identification and development in sport (pp. 11-18). London: Routledge. 
Singer, R. N., \& Janelle, C. M. (1999). Determining sport expertise: from genes to supremes. International Journal of Sport Psychology, 30, 117-150.

Syed, M. (2010). Bounce: the myth of talent and the power of practice. London: Fourth Estate.

Tedesqui, R., \& Young, B.W. (2015). Perspectives on active and inhibitive self-regulation relating to the deliberate practice activities of sport experts. Talent Development \& Excellence, 7, 29-39.

Tedesqui, R. A., \& Young, B. W. (2017a). Investigating grit variables and their relations with practice and skill groups in developing sport experts. High Ability Studies, 28(2), 167180.

Tedesqui, R. A., \& Young, B. W. (2017b). Associations Between Self-Control, Practice, and Skill Level in Sport Expertise Development. Research Quarterly for Exercise and Sport, 88(1), 108-113.

Toering, T. T., Elferink-Gemser, M. T., Jordet, G., \& Visscher, C. (2009). Self-regulation and performance level of elite and non-elite youth soccer players. Journal of Sports Sciences, 27, 1509-1517.

Tucker, R., \& Collins, M. (2012). What makes champions? A review of the relative contribution of genes and training to sporting success. British Journal of Sports Medicine, 46, 555561.

Vaeyans, R., Lenoir, M., Williams, A. M., \& Philippaerts, R. M. (2008). Talent identification and development programmes in sport: Current models and future directions. Sports Medicine, 38, 703-714.

Vandorpe, B., Vandendriessche, J. B., Vaeyens, R., Pion, J., Lefevre, J., Philippaerts, R. M., \& Lenoir, M. (2012). The value of a non-sport-specific motor test battery in predicting performance in young female gymnasts. Journal of Sports Sciences, 30, 497-505.

VanHaaren, T. (2017). Hawaii offers scholarship to Titan Lacaden, fifth-grade QB (June 13, 2017). Retrieved from: http://www. espn.com/college-football/story/_/id/19625713/hawaiirainbow-warriors-offer-scholarship-fifth-grader (accessed: 06/15/2017).

Vlahovich, N., Fricker, P. A., Brown, M. A., \& Hughes, D. (2017). Ethics of genetic testing and research in sport: A position statement from the Australian Institute of Sport. British Journal of Sports Medicine, 51, 5-11.

Ward, P., Hodges, N. J., Starkes, J. L., \& Williams, A. M. (2007). The road to excellence: Deliberate practice and the development of expertise. High Ability Studies, 18, 119-153.

Wattie, N. \& Baker, J. (2017). Why conceptualizations of talent matter: Implications for skill acquisition and talent identification and development. In J. Baker, S. Cobley, J. Schorer and N. Wattie (Eds.) Routledge handbook of talent identification and development in sport (pp. 69-79). London: Routledge.
Webborn, N., Williams, A., McNamee, M., Bouchard, C., Pitsiladis, Y., Ahmetov, I., Ashley, E., Byrne, N., Camporesi, S., \& Collins, M. (2015). Direct-to-consumer genetic testing for predicting sports performance and talent identification: Consensus statement. British Journal of Sports Medicine, 49, 14861491. 


\title{
Innate Talent in Sport: Beware of an organismic asymmetry - comment on Baker \& Wattie
}

\author{
Keith Davids ${ }^{1, *}$ \& Duarte Araújo ${ }^{2}$ \\ 1 Centre for Sports Engineering Research, Sheffield Hallam University, UK \\ 2 CIPER, Faculdade de Motricidade Humana, Universidade de Lisboa, Lisbon, Portugal \\ * Corresponding author: Centre for Sports Engineering Research, Sheffield Hallam University, 11 Broomgrove Road, Sheffield S10 2LX, UK \\ Tel: +44 (0)114225 2255 \\ E-Mail: k.davids@shu.acu.uk
}

\section{COMMENTARY}

\section{Article History:}

Submitted $5^{\text {th }}$ January 2019

Accepted $1^{\text {st }}$ February 2019

Published $7^{\text {th }}$ May 2019

\section{Handling Editor:}

Lisa Steidl-Müller

University of Innsbruck, Austria

Editor-in-Chief:

Martin Kopp

University of Innsbruck, Austria

\begin{abstract}
Of fundamental, theoretical and practical, relevance to sport science is the conceptualisation of talent, skill and expertise. Revisiting the question of innate talent is timely, given current pressure on young children selected to specialise in sport at an early age. Here, we re-iterate the conceptualisation of talent, skill and expertise in sport as an increasingly functional relationship between an athlete and a specific performance environment, developed over the macro-timescale of years and decades. This ecological dynamics rationale avoids an organismic asymmetry, the bias towards explanations of human behaviour which over-emphasise the role of inherent properties and qualities, identifiable through early selection. An ecological dynamics rationale, eschewing the organismic asymmetry of innate talent, in favour of exploiting and developing individual functionality in specific performance environments, challenges coaches and sport scientists to collaborate in new models for developing talent, skill and expertise.
\end{abstract}

Keywords:

Talent development - skill adaptation - ecological dynamics - organismic asymmetry- personenvironment interactions

Citation:

Davids, K. \& Araújo, D. (2019): Innate Talent in Sport: Beware of an organismic asymmetry - comment on Baker \& Wattie Current Issues in Sport Science, 4:102. doi: 10.15203/CISS_2019.102

This is a commentary on a CISS report article authored by Baker, J. \& Wattie, N. (2018). Innate talent in sport: Separating myth from reality. Current Issues in Sport Science, 3:006. doi: 10.15203/CISS_2018.006

\section{Introduction}

Baker and Wattie's re-examination of the concept of innate talent promotes a useful re-evaluation of this original proposition in psychology, but particularly drew our attention to two key, take-home messages: (i) their conclusion that the concept of innate talent had some validity, and (ii), that it also had limited practical utility for sports organisations.

Here, we discuss how conceptualisation of talent from an ecological dynamics perspective is not aligned with the first of Baker and Wattie's messages. The conceptualisation of 'talent' as innate does, however, raise significant questions about other human characteristics, and more practically, about how it can be utilized by sports organizations to develop athletes. This is not a trivial matter, as noted by Baker and Wattie, since currently much time and effort in system development and practitioner support is devoted in organized sport for early identification and selection of 'talented' children predicted to succeed at the highest performance levels.

Previously, we proposed, utilising the conceptualization of ecological dynamics and empirical data, how copious financial support and time involved in talent identification and early selection is misplaced due to a fundamental organismic asymmetry or biased explanation for behaviour centred on internal entities 
(Davids \& Araújo, 2010). The inherent nonlinearity of learning, development, and expertise in sport, strikingly highlights the misconceptions of a priori talent identification. Conceptualization of humans as complex adaptive systems, with nonlinear trajectories observed at different timescales (e.g., growth and maturation, development and learning), raises important questions, including: Why would measuring a putative innate property at birth or in the foetus be relevant for predicting later sport performance? Such properties, measured at those specific points in time, could be considered innate, but will certainly change over time due to interacting constraints of gene interactions, epigenetics, experiences, and chance. Moreover, whichever property (e.g., genes, molecular composition or hormonal markers) is measured after conception could never be considered as innate with certainty, given that development and environmental constraints are already influencing it and its relevance. Instead, these questions signal the supremacy of human adaptation and learning emanating from continuous individual-environment interactions (Araújo \& Davids, 2011).

Talent development is predicated on functionality of individualenvironment interactions

Due to centrality of individual-environment interactions in human behaviour, an ecological dynamics rationale places a greater emphasis on talent development in sport, defining talent, wrapped up with skill and expertise, not as innate qualities which individuals either have or do not have, but rather as: an increasingly functional relationship developed between a performer and a specific performance environment over macrotimescales (Davids, Güllich, Araújo \& Shuttleworth, 2017).

What does a functional relationship with a competitive performance environment in sport look like? Of fundamental importance is an athletess capacity to attain intended task goals during performance, predicated on consistently achieving performance outcomes and results, by satisfying constraints of ever-changing competitive environments. Functional behaviours emerge in competitive performance environments and relevant performance solutions may vary over different timescales for athletes, including: (i) within individuals during performance, and athletic development (through motor learning, changes in effectivities - capacities and skills -, adaptations to training and conditioning or through growth and maturation); and (ii), over the macro-timescale of years and decades as sports evolve, constrained by innovations in tactical trends, sport formats, playing surfaces, rules and regulations, and updated equipment and technology. These changes shape sports over time and are rarely predictable, illustrating the futility of defining innate talent in young children.

An athlete's capacity to functionally interact with varied and dynamic performance constraints is predicated on dexterity (adaptive flexibility). Insights on dexterity were provided by Nikolai Bernstein, the Russian physiologist who has had an enormous impact on theoretical development in the human movement sciences. Bernstein (1967) suggested that dexterity involves the continuous re-organisation of functional adaptive behaviours through exploratory learning. Bernstein (1967, pp. 228) conceptualized dexterity as "the ability to find a motor solution for any external situation, that is, to adequately solve any emerging motor problem correctly (i.e., adequately and accurately), quickly (with respect to both decision making and achieving a correct result), rationally (i.e., expediently and economically), and resourcefully (i.e., quick-wittedly and initiatively)" (italics in the original).

\section{The importance of Athlete Intrinsic Dynamics}

The fundamentality of an individual's dexterous interactions with a specific performance environment in sport has clear implications for understanding what each individual athlete can contribute to functioning in a specific performance environment. Whilst we have proposed that there is no role for an entity termed innate talent, we have previously highlighted the importance of intrinsic dynamics in athletes as complex adaptive systems (Araújo \& Davids, 2011). Kelso (1995) referred to intrinsic system dynamics as dispositional tendencies, propensities, capacities, and abilities that differ amongst individuals. The foundational capacities supported by an individual's intrinsic dynamics can be more or less functionally effective for stabilizing successful performance behaviours. An individual's intrinsic dynamics underpin self-regulation in sport performance, supporting the physical, cognitive, perceptual, psychological and emotional, and social interactions that emerge during performance (Davids et al., 2017). Intrinsic dynamics of complex adaptive systems are aligned with effectivities, referred to in ecological psychology as capacities for utilising affordances (opportunities for action), in specific performance domains. When an athlete's intrinsic dynamics cooperate with task dynamics in specific domains, then performance functionality will be enhanced (but goal achievement is still not guaranteed). Competing intrinsic and task dynamics can lead to misaligned relations between an athlete and a sport, providing a barrier to success at the highest levels (Seifert et al., 2016). Some tendencies can, of course, be transferrable in the sense of satisfying non-specific domain performance demands. It is important to note that this conceptualisation of transferability of dispositional tendencies in physical, cognitive, emotional and social interactions are harmonious with key ideas of a practitioner-led model of skill acquisition and talent development in high performance sport: The Athletics Skills Model (Wormhoudt et al., 2018). The ASM motto is 'first the athlete, then the specialist' promoting the view that, while the capacity to function at the highest performance levels may be domain-specific, the self-regulating nature of athlete functioning is deeply underpinned by non-domain specific capacities and evolving dispositional tendencies which may be psych-social, physical, and emotional.

In this way, ecological dynamics captures how some individuals may be predisposed over time towards functioning more effectively and efficiently in some sports environments than 
others. This approach does not preclude attempts to predict which athletes may have a greater potential to perform at the highest levels, the aim being to identify athletes with dispositional tendencies, in varied dimensions, to function effectively in specific performance contexts (over years and decades: the macro-timescale of sport development). The problem is not in the practice, but in the rationale for talent as innate.

A fruitful approach to meeting this challenge may be to design tasks which can help to assess and develop an individual's effectivities over time (de-prioritising current performance levels) and which may underpin future performance in specific sports. Clarification of specific tasks constraints of a competitive performance context that need to be satisfied, as well as their variations, (task dynamics) is needed in future research (Woods et al., 2016) . However, it is important to heed evidence that analytics of sport performance at one specific point in time early in an athlete's career do not necessarily correspond to future performance at a senior level (Güllich, 2018).

\section{Summary}

We have proposed that talent, conceived as some individual innate entity that can predict exceptional future performance in young athletes, is an inadequate concept for sport science research and practice, i.e., more in the realm of myth and supposition than in scientific reality. Aligned with the approach advocated in the second key message of Baker and Wattie it is worth asking: What may be the main practical implications of an ecological dynamics conceptualisation of talent, skill and expertise in sport as increasingly functional adaptation and enhanced self-regulation of an individual in a specific performance environment? First, an important role seems to exist for identifying underlying tendencies, dispositions and capacities related to successful performance in specific domains which may signal future potential for individual functionality. In discerning athlete potential, the experiential knowledge of elite practitioners needs to be integrated with empirical knowledge over the extended macro-timescale of years and decades in high performance sports organisations (see Woods et al., 2016). Second, due to multiple dimensions of, and pathways, to successful athlete functioning in sport (Araújo \& Davids, 2010; Phillips et al., 2010), new models of coaching and athlete development are needed which integrate the work of specialist practitioners (Renshaw, Davids, Newcombe \& Roberts, 2019). Finally, these new models of athlete learning and preparation in the micro-structure of practice signal the need for a better balance between early specialisation in specific sport domains and the exploitation and development of general, transferable, functional tendencies which can be harnessed later over the macrotimescale of talent development (Wormhoudt et al., 2018).

\section{Funding}

DA was partially funded by the Fundação para a Ciência e Tecnologia, under Grant UID/DTP/ UI447/2019 to CIPER-Centro Interdisciplinar para o Estudo da Performance Humana (unit 447).

\section{Competing Interests}

The author(s) has/have declared that no competing interests exist.

\section{Data Availability Statement}

All relevant data are within the paper.

\section{References}

Araújo, D. \& Davids, K. (2011). Talent Development: From Possessing Gifts, to Functional Environmental Interactions. Talent Development and Excellence 3, 23-26.

Bernstein, N. A. (1967). The co-ordination and regulation of movements. London, England: Pergamon Press.

Davids, K. \& Araújo, D. \& (2010). The concept of 'Organismic Asymmetry' in sport science. Journal of Science and Medicine in Sport 13, 633-640.

Davids, K., Güllich, A., Araújo, D. \& Shuttleworth, R. (2017). Understanding environmental and task constraints on athlete development: Analysis of micro-structure of practice and macro-structure of development histories. In Routledge Handbook of Talent Identification and Development in Sport (Edited by J. Baker, S. Cobley, J. Schorer \& N. Wattie), pp.192206. Routledge: London.

Güllich, A. (2018). Sport-specific and non-specific practice of strong and weak responders in junior and senior elite athletics - A matched-pairs analysis. Journal of Sports Sciences, DOI: 10.1080/02640414.2018.1449089

Kelso JAS (1995). Dynamic Patterns: The Self-Organization of Brain and Behavior. Cambridge, MA: MIT Press

Phillips, E., Davids, K., Renshaw, I., \& Portus, M. (2010). Expert Performance in Sport and the Dynamics of Talent Development. Sports Medicine 40, 271-283.

Renshaw, I., Davids, K., Newcombe, D. \& Roberts, W. (2019). The Constraints-Led Approach: Principles for Sports Coaching and Practice Design (1st Ed.). Routledge Studies in Constraints-Based Methodologies in Sport. London: Routledge.

Seifert, L., Wattebled, L., Orth, D., L'Hermette, M., Boulanger, J. \& Davids, K. (2016). Skill transfer specificity shapes perception and action under varying environmental constraints. Human Movement Science 48, 132-141. 
Woods, C.T., McKeown, I., Haff, G.G. \& Robertson, S. (2016). Comparison of athletic movement between elite junior and senior Australian football players. Journal of Sports Sciences, 34, 1260-1265, DOI: 10.1080/02640414.2015.1107185

Wormhoudt, R., Savelsbergh, G.J.P., Teunissen, J.W. \& Davids, K. (2018). The Athletics Skills Model: Optimizing talent development through movement education. Routledge: London. 


\title{
The talent quest - comment on Baker \& Wattie
}

\author{
Irene R. Faber ${ }^{1,2, *}$
}

1 Sports Science Institute, University of Oldenburg, Oldenburg, Germany

2 International Table Tennis Federation, Lausanne, Switzerland

* Corresponding author: Sports Science Institute, University of Oldenburg, Ammerländer Heerstraße 114-118, 26129 Oldenburg, Germany Tel: +31 (0) 620030686

E-Mail: irene.faber@uol.de

\section{COMMENTARY}

\section{Article History:}

Submitted $4^{\text {th }}$ February 2019

Accepted $12^{\text {th }}$ February 2019

Published $7^{\text {th }}$ May 2019

Handling Editor:

Lisa Steidl-Müller

University of Innsbruck, Austria

Editor-in-Chief:

Martin Kopp

University of Innsbruck, Austria

\section{ABSTRACT}

Explaining exceptional human performance remains problematic. Baker \& Wattie (2018) explored the value of innate talent as underlying cause for excellence in sports. Although the absence of the influence of biological genetic influences cannot be confirmed or rejected, it is recommended to discuss this topic while taking into account the time-depending sport-specific context. Moreover, if, as Baker \& Wattie (2018) concluded, the concept of talent has limited utility to the world of sport, the use of the predicate 'talent' might better be reconsidered in practice.

Keywords:

Aptitude - Sports - Giftedness

Citation:

Faber, I. R. (2019): The talent quest - comment on Baker \& Wattie Current Issues in Sport Science, 4:103. doi: 10.15203/CISS_2019.103

This is a commentary on a CISS report article authored by Baker, J. \& Wattie, N. (2018). Innate talent in sport: Separating myth from reality. Current Issues in Sport Science, 3:006. doi: 10.15203/CISS_2018.006

Curiosity and the drive to explain phenomena are typical characteristics of human beings and maybe even most noticeable in scientists. One of the quests that still attracts a lot of scientists working in different fields is to reveal the mystery of exceptional human performance (Ericsson, 2006; Rees et al., 2000). How can we explain the special and unique level of ability? And maybe even more important nowadays, can we predict excellence already at an early stage? An innate predisposition or so-called 'innate talent' has been proposed and explored by many as a possible explanation for exceptionality in both the academic and practical contexts. As Baker \& Wattie (2018) point out in their review, this is undoubtedly the case in the domain of sports. The policies of national sport association/clubs are generally focused on effective and efficient athletes' development programs to yield international successes (Vaeyens, Güllich, Warr, \& Philippaerts, 2009). Early identification of those athletes with the highest probability to win future medals is considered crucial to keep up with the global medal race. Getting a grip on exceptional performance and the search for high potential athletes is of main concern. Baker and Wattie (2018) present some examples how people rely on the 'talent account' in real-life sports. It is clear that the discussion raised by Baker \& Wattie (2018) about the validity of 'innate talent' as an explanation for excellence is of relevance. The purpose of this comment is to highlight some issues that, to my opinion, were not included or scarcely addressed by the authors.

In their discussion about the validness of the concept of innate talent, Baker \& Wattie (2018) mainly focus on the genetic predisposition of anthropometrics and physiological capacity that align with the demands in certain sports. Specifically, being taller is considered to be a genetic advantage or innate talent. However, in many sports a specific height is not a clear advantage (e.g. badminton, field hockey, table tennis, soccer) (Elferink-Gemser, Visscher, Lemmink, \& Mulder, 2004; Keogh, Weber, \& Dalton, 2003; Pion et al., 2015; Reilly, Bangsbo, \& Franks, 2000). The athletes' profiles might differ even at the highest competition level using strengths to compensate for weaknesses; for example, within the world's top 10 ranking in 
badminton (January 2019) height differs from $1.75 \mathrm{~m}$ to $1.94 \mathrm{~m}$ between men and from $1.56 \mathrm{~m}$ to $1.79 \mathrm{~m}$ for women (https:// bwfbadminton.com/rankings/). Therefore, the reasoning might be valid for specific sports, but not to all. Moreover, the importance of being taller might be overestimated in certain sports as a result of the selection policies and the developmental system used in youth sports. Being taller can be a temporary advantage during youth development. If the identification and selection of 'talented' players take place within this period, it is likely that the taller and probably more mature players will be selected especially when the focus is to win already in youth sport. If the development program prevents entry at a later point in time, only the taller/early mature players will survive in the system. This can lead to a misinterpretation of height being a talent indicator. Thus, the validness of innate talent concerning anthropometric predisposition might not hold in all sports. The same could be true for other physical genetic predispositions. It is often not clear what the exact determinants for future success are in a certain sport and temporary advantages could be wrongly construed as talent indicators. Although this does not wipe away the possible influence of biology, it recommends a careful consideration per sport and its context.

Also for other reasons, the sport's context is an important factor that should be taken into account when explaining human excellence. Some sports are popular all around the world and have been practiced intensively for many decades by many athletes while other sports are relatively young, less widespread and only practiced by a small number. It is likely that in the latter case, performance differences can be validly explained by differences between athletes in the amount and quality of deliberate practice (Ericsson, 2006). The role of innate talent might be negligible or even absent. Furthermore, it is important to acknowledge the role of chance in the pursuit of excellence (Gagne, 2004). The coincidental presence of among other things the right club, trainer, team mates and sparring partners will influence the opportunities for development, even as the accidental presence of the athlete and the talent scout at the place at the same time and the scout actually seeing the right performance at the right moment. Even when an athlete might have the accurate genetic predisposition to excel in a certain sport, the environment needs to recognize and value this at the right place and time. As an extension to this, Baker \& Wattie (2018) plead for more credence to coaches' intuition or 'gutfeeling' to early identify talent and use this as another argument in favor of the validness of the talent account. Although I value the expertise of coaches to a large extent, I also need to admit, based on the large datasets from many sports revealing relative age effects, that their judgement concerning the selection of players is often biased (Musch \& Grondin, 2001). Moreover, Howe, Davidson and Sloboda (1998) already argued that early abilities are often better explained by difference in opportunities than innate talent without discarding the possibility of innate talent.

In conclusion, explaining exceptional performance and defining talent in sports remains a challenge. It requires a holistic approach in which sport-specific aspects need to be taken into account. It also seems a semantic challenge to speak the same language within science and practice. As Baker \& Wattie (2018) concluded, the concept of talent indeed seems to have limited utility to the world of sport. In addition to this, the use of the predicate 'talent' might better be reconsidered in practice.

\section{Funding}

The author(s)s has/have no funding or support to report.

\section{Competing Interests}

The author(s) has/have declared that no competing interests exist.

\section{Data Availability Statement}

All relevant data are within the paper.

\section{References}

Ackerman, P. L. (2014). Nonsense, common sense, and science of expert performance:Talent and individual differences. Intelligence, 45, 6-17. doi: 10.1016/j.intell.2013.04.009

Baker, J., Schorer, J., \& Wattie, N. (2018). Compromising talent: Issues in identifying and selecting talent in sport. Quest, 70(1), 48-63. doi: 10.15203/CISS_2018.006

Elferink-Gemser, M., Visscher, C., Lemmink, K., \& Mulder, T. (2004). Relation between multidimensional performance characteristics and level of performance in talented youth field hockey players. Journal of Sports Sciences, 22(11-12), 1053-1063. doi: 10.1080/02640410410001729991

Ericsson, K. A. (2006). The influence of experience and deliberate practice on the development of superior expert performance. The Cambridge handbook of expertise and expert performance, 38, 685-705.

Gagné, F. (2004). Transforming gifts into talents: The DMGT as a developmental theory. High ability studies, 15(2), 119-147. doi: 10.1080/1359813042000314682

Howe, M. J., Davidson, J. W., \& Sloboda, J. A. (1998). Natural born talents undiscovered. Behavioral and brain sciences, 21(3), 432-437. doi: 10.1017/S0140525X9800123X

Keogh, J. W., Weber, C. L., \& Dalton, C. T. (2003). Evaluation of anthropometric, physiological, and skill-related tests for talent identification in female field hockey. Canadian Journal of Applied Physiology, 28(3), 397-409. doi: 10.1139/h03-029

Musch, J., \& Grondin, S. (2001). Unequal competition as an impediment to personal development: A review of the relative age effect in sport. Developmental review, 21(2), 147-167. doi: $10.1006 /$ drev.2000.0516 
Pion, J., Segers, V., Fransen, J., Debuyck, G., Deprez, D., Haerens, L., ... \& Lenoir, M. (2015). Generic anthropometric and performance characteristics among elite adolescent boys in nine different sports. European journal of sport science, 15(5), 357-366. doi: 10.1080/17461391.2014.944875

Rees, T., Hardy, L., Güllich, A., Abernethy, B., Côté, J., Woodman, T., ... \& Warr, C. (2016). The great British medalists project: a review of current knowledge on the development of the world's best sporting talent. Sports Medicine, 46(8), 10411058.

Reilly, T., Bangsbo, J., \& Franks, A. (2000). Anthropometric and physiological predispositions forelite soccer.JournalofSports Sciences, 18(9), 669-683. doi: 10.1080/02640410050120050

Baker, J., Schorer, J., \& Wattie, N. (2018). Compromising talent: Issues in identifying and selecting talent in sport. Quest, 70(1), 48-63. doi: 10.1080/00336297.2017.1333438

Vaeyens, R., Güllich, A., Warr, C. R., \& Philippaerts, R. (2009). Talent identification and promotion programmes of Olympic athletes. Journal of Sports Sciences, 27(13), 1367-1380. doi: 10.1080/02640410903110974 


\title{
Beyond nature vs. nurture in expertise research - comment on Baker \& Wattie
}

\author{
David Z. Hambrick ${ }^{1, *}$ \& Alexander P. Burgoyne ${ }^{1}$ \\ 1 Department of Psychology, Michigan State University, East Lansing, Michigan, USA \\ * Corresponding author: Department of Psychology, Michigan State University, East Lansing, Ml 48824, United States, Tel: +01 517-303-1304 \\ E-Mail: hambric3@gmail.com
}

\section{COMMENTARY}

\section{Article History:}

Submitted $21^{\text {st }}$ February 2019

Accepted $6^{\text {th }}$ March 2019

Published $7^{\text {th }}$ May 2019

Handling Editor:

Lisa Steidl-Müller

University of Innsbruck, Austria

Editor-in-Chief:

Martin Kopp

University of Innsbruck, Austria

\section{ABSTRACT}

The field of expertise is mired in a nature vs. nurture debate. Despite what we now know from behavioral genetics research about the underpinnings of human behavior, some expertise theorists continue to deny or downplay the importance of genetic factors ("innate talent") in expert performance. In this commentary, we argue that this viewpoint is neither defensible nor productive. Our argument is based on two observations. First, there are always limits on human performance, even among individuals who have engaged in long periods of intensive training. Second, grounded in a neurobiological system that has evolved through natural selection, variation across people in phenotypes reflecting these limits will have a genetic component. We comment on directions for future research to advance the field of expertise.

Keywords:

Talent - expertise - individual differences - sports - training - natural selection

Citation:

Hambrick, D. Z. \& Burgoyne, A. P. (2019): Beyond nature vs. nurture in expertise research - comment on Baker \& Wattie Current Issues in Sport Science, 4:104. doi: 10.15203/CISS_2019.104

This is a commentary on a CISS report article authored by Baker, J. \& Wattie, N. (2018). Innate talent in sport: Separating myth from reality. Current Issues in Sport Science, 3:006. doi: 10.15203/CISS_2018.006

The scientific debate about whether innate talent plays a role in expert performance began more than a century and a half ago. Showing that eminent individuals tended to be biologically related, Sir Francis Galton (1869) argued in his book Hereditary Genius that greatness arises from "natural ability". The Swiss botanist Alphonse Pyrame de Candolle (1873), presenting his own data, countered that causes favorables-advantages such as wealth, education, and even a temperate climate-are the major factors in success. The debate has raged on ever since. It is a bit perplexing that we are still having this debate. Other fields long ago embraced the idea that nature and nurture, and their interplay, contribute to variation in human behavior. We are decades past any serious debate about whether traits such as intelligence, personality, and psychopathology are heritable (they are-substantially so). Nearly twenty years ago, the behavioral geneticist Eric Turkheimer (2000) wrote, "The nature- nurture debate is over. The bottom-line is that everything is heritable" (p. 160). Yet, here we are, having a debate about whether innate talent is a valid concept.

To be clear, no credible scientist believes that expert performance can be explained without recourse to nurture (i.e., the environment). This is because the type of specialized knowledge necessary for activities such as chess, music, and sports can only be acquired through some form of environmental exposure (i.e., training and other activities). We don't come into the world as "blank slates," but we certainly aren't born knowing the rules of chess, much less the Queen's Gambit.

Nevertheless, the view that expert performance can be explained without recourse to talent remains popular in both scientific and popular circles. John Watson (1924), the founder of behaviorism, famously guaranteed he could train any healthy infant to become "any type of specialist ...regardless of his 
talents" (p. 104). More recently, K. Anders Ericsson (2007) wrote, "it is possible to account for the development of elite performance among healthy children without recourse to unique talent (genetic endowment)" (p. 4). This view has been promoted in popular books on expertise, such as Talent is Overrated: What Really Separates World-Class Performers from Everybody Else (Colvin, 2010), The Talent Code: Greatness Isn't Born. It's Made. Here's How (Coyle, 2009), and Peak: Secrets from the New Science of Expertise (Ericsson \& Pool, 2016). The psychologist Scott Miller (2011) blogged, "What is widely believed however is not always true: flat earth, phrenology, cold fusion, and...innate talent."

The question of why the field of expertise remains mired in a nature vs. nurture debate while other fields have progressed is interesting to consider. Dogma dies hard, perhaps. However, this is a question for historians of science. Here, in this commentary on Joseph Baker and Nick Wattie's thoughtful target article, we offer our perspective on talent and thoughts on how to advance the field of expertise.

\section{The Inevitability of Heritability}

A decade before Galton published Hereditary Genius (1869), his half-cousin Charles Darwin published On the Origin of Species (1859). Darwin's revolutionary insight was that populations evolve through natural selection: the differential survival of members of a population based on differences in their characteristics. The upshot of natural selection is a discovery so robust that it has been dubbed the First Law of Behavioral Genetics (Turkheimer, 2000): if a behavioral characteristic (a phenotype) varies across people, there will be some contribution of genetic factors to that variation (Plomin, DeFries, Knopik, \& Neiderhiser, 2016; Sela \& Barbaro, 2018).

In view of this discovery, it would seem odd to argue that expert performance can be explained without recourse to genetic endowment-and it is odd. Through training, people can develop skills that enable them to circumvent normal limits on human performance (Ericsson, 2014; Ericsson \& Pool, 2016). This is not a controversial claim; this is the only sensible way to explain the feats of elite performers. Take "memory athletes" such as Lance Tschirhart, who holds the world record for memorizing random digits (at a bewildering 456; World-MemoryStatistics.com, 2016). Tschirhart is not holding 456 digits in his short-term memory; rather, through training, he has acquired skill in storing digits in long-term memory (see Ericsson, Chase, \& Faloon, 1980).

However, just because people can circumvent limits on performance does not mean that performance is without limits. There are always limits on human performance (and, for that matter, the performance of artificial systems such as Deep Blue). Circumvent one limit, and there will be others. Moreover, reflecting a neurobiological system that has evolved through natural selection, there will be heritable variation across people in phenotypes indexing those limits, whether they be cognitive phenotypes such as working memory, physical phenotypes such as height, neurological phenotypes such as white matter integrity, physiological phenotypes such as maximal oxygen uptake $\left(\mathrm{VO}_{2 \max }\right)$, or whatever. The level of these phenotypes will have an impact on a person's development in a domain (or lack thereof). Basketball and height is only the most obvious example: there have been only three players 5 -feet- 6 or shorter in NBA history ("24 Shortest NBA Players").

In short, there is no plausible reason to deny that talent impacts expert performance. All the same, it is important to ask what, exactly, talent is; otherwise, it might as well not exist because it can't be measured. Baker and Wattie (2019) provide a useful discussion. Along the lines just discussed, they argue that talent is a valid concept, because it must be: "An evolutionary probabilistic standpoint assumes there is a distribution of ability and/or individual characteristics (i.e., degrees of talent) across a population with very small numbers of individuals at the very highest and lowest levels" (Baker \& Wattie, 2019, p. 4). They add, however, that "with the exception of a few variables related to body size, no robust indicators of talent currently exist" (p. 7). We are surprised by this claim. Numerous twin studies have found moderate-to-large heritability estimates for sports-relevant physiological characteristics. For example, a recent meta-analysis found average heritability of $59 \%$ for $\mathrm{VO}_{2 \max }$ (Schutte, Nederend, Hudziak, Bartels, \& de Geus, 2016). $\mathrm{VO}_{2 \max }$ can be increased with training (see, e.g., Skinner et al., 2001), but so can many highly heritable phenotypes (e.g., muscle mass; Aagaard et al., 2004; Georgiades, Klissouras, Baulch, Wang, \& Pitsiladis, 2017). Heritability and modifiability are independent considerations.

\section{Intellectual Talent}

We further note that psychologists discovered a robust indicator of intellectual talent well over a century ago. Given a reasonably large and representative sample of subjects, scores on tests of different cognitive abilities will correlate positively with each other, implying the existence of a general factor of intelligence (Jensen, 1998). This " $g$ " factor is one of the most replicated findings in psychological science. Three things about $g$ are clear (see Ritchie, 2015). First, there is just one $g$. Correlations between estimates of $g$ extracted from different test batteries are near 1.0 (Johnson, Bouchard, Krueger, McGue, \& Gottesman, 2004). Second, $g$ is stable across time. A person high in $g$ in childhood will likely be so for the rest of their life (Deary, Whalley, Lemmon, Crawford, \& Starr, 2000). Finally, $g$ has practical utility. It predicts socially relevant outcomes such as academic achievement and job performance better than any other single variable (Schmidt \& Hunter, 2004).

There is relatively little evidence for the role of $g$ in developing sports expertise. Significant correlations between measures of cognitive ability and sports performance have sometimes been observed, but just as often not (see Hambrick, Burgoyne, \& Oswald, 2019, for a review). Nevertheless, we think that a con- 
sideration of the role of innate talent in sports expertise must include $g$. The question of why $g$ sometimes predicts sports performance, but other times not, is particularly interesting. It could be that $g$ predicts performance in individual sports but not group sports in which team-level factors may compensate for individual-level factors. Research aimed at answering this type of question will enrich our understanding both of $g$ as a form of intellectual talent, and of the underpinnings of sports expertise.

\section{Conclusion}

Research on the nature and nurture of complex skill will move the field of expertise ahead. The knowledge gained from this research will provide a scientific foundation for accelerating the acquisition of expert performance. For example, as is already being done in sports, it may one day be possible to tailor training in domains such as music based on performers' genotypes. Far from limiting people's potential, this type of intervention will bring expert performance within reach of more people than is currently the case.

\section{Funding}

The author(s)s has/have no funding or support to report.

\section{Competing Interests}

The author(s) has/have declared that no competing interests exist.

\section{Data Availability Statement}

All relevant data are within the paper.

\section{References}

24 shortest NBA players to ever take the course (February 14, 2018). Hero Sports. Retrieved from: https://herosports.com/ nba/shortest-nba-players-muggsy-bogues-earl-boykinskeith-jennings-spud-webb-aiai

Aagaard, P., Andersen, J. L., Dyhre-Poulsen, P., Leffers, A. M., Wagner, A., Magnusson, S. P., Halkjær-Kristensen, J., \& Simonsen, E. B. (2001). A mechanism for increased contractile strength of human pennate muscle in response to strength training: changes in muscle architecture. The Journal of Physiology, 534, 613-623.

Baker, J., \& Wattie, N. (2018). Innate talent in sport: Separating myth from reality. Current Issues in Sport Science (CISS), 3, 1-9.
Carmichael, C. M., \& McGue, M. (1995). A cross-sectional examination of height, weight, and body mass index in adult twins. Journals of Gerontology: Biological Sciences, 50A, B237-B244.

Colvin, G. (2010). Talent is overrated: What really separates worldclass performers from everybody else. New York City, NY: Penguin.

Coyle, D. (2009). The talent code: Greatness isn't born, it's grown. And here's how. New York City, NY: Random House.

Darwin, C. (1859). On the origin of species. Retrieved from https://www.gutenberg.org/files/2009/2009-h/2009-h.htm

de Candolle, A. P. (1873). Histoire des Sciences et des Savants Depuis Deux Siècles. Retrieved from http://biodiversitylibrary. org/page/27318242\#page/10/mode/1up

Deary, I. J., Whalley, L. J., Lemmon, H., Crawford, J. R., \& Starr, J. M. (2000). The stability of individual differences in mental ability from childhood to old age: follow-up of the 1932 Scottish Mental Survey. Intelligence, 28, 49-55.

Ericsson, K. A. (2007). Deliberate practice and the modifiability of body and mind: Toward a science of the structure and acquisition of expert and elite performance. International Journal of Sport Psychology, 38, 4-34.

Ericsson, K. A. (2014). Why expert performance is special and cannot be extrapolated from studies of performance in the general population: A response to criticisms. Intelligence, 45, 81-103.

Ericsson, A., \& Pool, R. (2016). Peak: Secrets from the new science of expertise. Boston, MA: Houghton Mifflin Harcourt.

Ericcson, K. A., Chase, W. G., \& Faloon, S. (1980). Acquisition of a memory skill. Science, 208(4448), 1181-1182.Ericsson, K. A., Krampe, R. T., \& Tesch-Römer, C. (1993). The role of deliberate practice in the acquisition of expert performance. Psychological Review, 100, 363-406.

Galton, F. (1869). Hereditary genius: An inquiry into its laws and consequences (Vol. 27). London, UK: Macmillan.

Georgiades, E., Klissouras, V., Baulch, J., Wang, G., \& Pitsiladis, Y. (2017). Why nature prevails over nurture in the making of the elite athlete. BMC Genomics, 18, 59-66.

Hambrick, D. Z., Burgoyne, A. P., \& Oswald, F. L. (2019). Domaingeneral models of expertise: The role of cognitive ability. In P. Ward, J. M. Schraagen, J. Gore, \& E. Roth (Eds.), The Oxford Handbook of Expertise. Oxford, UK: Oxford University Press.

Jensen, A. R. (1998). The $g$ factor: The science of mental ability (Vol. 648). Westport, CT: Praeger.

Johnson, W., Bouchard Jr, T. J., Krueger, R. F., McGue, M., \& Gottesman, I. I. (2004). Just one g: Consistent results from three test batteries. Intelligence, 32, 95-107.

Miller, S. (2011). Deliberate practice: What's all the fuss about. Archived: https://web.archive.org/save/https://www.scottdmiller.com/deliberate-practice-whats-all-the-fuss-about/

Plomin, R., DeFries, J. C., Knopik, V. S., \& Neiderhiser, J. M. (2016). Top 10 replicated findings from behavioral genetics. Perspectives on Psychological Science, 11, 3-23. 
Ritchie, S. (2015). Intelligence: All that matters. Hodder \& Stoughton.

Schmidt, F. L., \& Hunter, J. (2004). General mental ability in the world of work: occupational attainment and job performance. Journal of Personality and Social Psychology, 86, 162173.

Schutte, N. M., Nederend, I., Hudziak, J. J., Bartels, M., \& de Geus, E. J. C. (2016). Twin-sibling study and meta-analysis on the heritability of maximal oxygen consumption. Physiological Genomics, 48, 210-219.

Sela, Y. \& Barbaro, N. (2018). Evolutionary perspectives on personality and individual differences. In V. Zeigler-Hill \& T. K. Shackelford (Eds.), The SAGE handbook of personality and individual differences (pp. 203-228). London: Sage.

Skinner, J. S., Jaskólski, A., Jaskólska, A., Krasnoff, J., Gagnon, J., Leon, A. S., Rao, D. C., Wilmore, J. H., \& Bouchard, C. (2001). Age, sex, race, initial fitness, and response to training: the HERITAGE Family Study. Journal of Applied Physiology, 90, 1770-1776.

Turkheimer, E. (2000). Three laws of behavior genetics and what they mean. Current Directions in Psychological Science, 9, 160-164.

Watson, J. B. (1924). Behaviorism. New York: People's Institute. (Rev. Ed. 1930).

World-Memory-Statistics.com. (2016). Retrieved February 14, 2019, from http://www.world-memory-statistics.com/disciplines.php 


\title{
Innate talent is adaptable - comment on Baker \& Wattie
}

\author{
Michael Romann ${ }^{1, *}$ \\ 1 Swiss Federal Institute of Sport Magglingen (SFISM), Magglingen, Switzerland \\ * Corresponding author: Swiss Federal Institute of Sport Magglingen, Alpenstrasse 18, CH-2532 Magglingen, Switzerland \\ E-Mail:michael.romann@baspo.admin.ch
}

\section{COMMENTARY}

\section{Article History:}

Submitted $10^{\text {th }}$ December 2018

Accepted $21^{\text {th }}$ December 2018

Published $7^{\text {th }}$ May 2019

Handling Editor:

Lisa Steidl-Müller

University of Innsbruck, Austria

Editor-in-Chief:

Martin Kopp

University of Innsbruck, Austria

\section{ABSTRACT}

A recent article by Baker and Wattie (2018) provided an update on the widely cited review of "Innate Talent" by Howe, Davidson and Sloboda (1998). The article summarizes that the defined criteria for "Innate Talent" are still valid, standing the test of time. However, new findings in epigenetics should be considered. The epigenome interacts with environmental factors, such as physical exercise, contributing to phenotypical and performance differences of the same gene. In this context, researchers in sport science face the task of defining ethical standards that are accepted by society. From an epigenetic perspective, one should refrain from thinking that genetics have a fixed performance outcome, since the epigenome is adaptable. Instead, research and practice should consider how created environments support athlete development.

Keywords:

Aptitude - Sports - Giftedness

Citation:

Romann, M. (2019): Innate talent is adaptable - comment on Baker \& Wattie Current Issues in Sport Science, 4:105. doi: 10.15205/CISS_2019.105 This is a commentary on a CISS report article authored by Baker, J. \& Wattie, N. (2018). Innate talent in sport: Separating myth from reality. Current Issues in Sport Science, 3:006. doi: 10.15203/CISS_2018.006

\section{Introduction}

As a researcher in youth sport, I appreciate the article by Baker \& Wattie (2018), as it emphasizes the importance of talent development and the developmental process. It also provides a convincing overview of the history of research alongside recent findings on the topic of "Innate Talent". The extent to which physical performance of an individual is predetermined by genes has been a heavily discussed topic in (sport) science. Given the knowledge of genetic factors influencing physical performance, it has been suggested that genome analyses could potentially identify elite athletes from an early age (Rupert, 2003). It has also been suggested that such an approach could improve the time-consuming and expensive scouting procedures conducted for new athletic potential (Sharp, 2008). As a direct result of the decoding of the human genome in 2001 (Venter et al., 2001), the search for specific genes that influence and predict elite athletic performance has received a lot of attention. With the advancement of technology, the once simple idea of "one-gene-encodes-one-phenotype" was adapted several times and finally extended to the "one-geneone-polypeptide" definition (Gerstein et al., 2007). In future, the research on epigenetics in sport might have a significant impact on the design of talent development programs and ultimately, the performance of individual athletes. This comment therefore focuses on the concept of talent in sport, the rarely discussed key area of epigenetics, and the ethical implications of genetic testing and practical implications for sport science.

\section{Concept of talent in sport}

In the area of sporting talent development, recognized researchers present talent as a set of personal characteristics that enhance one's ability to achieve expertise at an accelerated rate in a specific sport (Vaeyens, Lenoir, Williams, \& Philippaerts, 2008). Likewise, they recognise that talent exists when certain individual prerequisites are combined with an effortful development process. Often, elite athletic performance is described as being the result of biological or genetically constrained fac- 
tors (i.e. nature) and the end-product of experience and learning (i.e. nurture) (Coutinho, Mesquita, Fonseca, \& De MartinSilva, 2014). On this basis, the aim of talent identification is to assess a person's potential for future performance (Rees et al., 2016; Vaeyens, Lenoir, Williams, \& Philippaerts, 2008). However, identifying and predicting performance potential at a young age is a difficult and complex process, as development is non-linear, unstable and multifactorial (Cobley \& Till, 2017). To further complicate matters, there are multiple interactions between prerequisites, which may change over time (SchmittNey, Happ, Ball, \& Groner, 1992; Cobley \& Till, 2017). While an individual's genome could be described as being relatively static, the epigenome can be dynamic, altered by environmental conditions and stimuli (to a degree). Epigenetics therefore provides the bridge between nature and nurture in the concept of talent.

\section{Epigenetics}

Epigenetics is the term used to describe inheritable changes in gene expression that are not based on changes in the DNA sequence. In other words, a change in the phenotype while the genotype remains the same. Epigenetic changes are a regular, natural and reversible event (Egger, Liang, Aparicio, \& Jones, 2004). The epigenome consists of nuclear information that is hereditary during cell division and controls development, tissue differentiation and cellular responsiveness. Epigenetic information is controlled by the genome sequence, environment, stochastics and chance. As such, epigenetics is at the interface between genome, development and environmental exposure (Feinberg, 2018). There is growing evidence that athletic performance is influenced not only by the mere genetic code, but also by numerous processes that influence gene expression transcriptionally and post-transcriptionally and that some form of gene-for-environment interaction exists (Ehlert, Simon, \& Moser, 2013). Epigenetic effects can therefore play a significant role in the expression and determination of athletic potential (Rees et al., 2016). At the genetic and epigenetic level, there is evidence that gene variants explain a significant amount of variance in a variety of expressions such as endurance and muscle strength, which in turn are influenced by physiological processes, such as physical exercise (Haugaasen, Toering, \& Jordet, 2014; Rees et al., 2016). Fraga \& colleagues (2005) provided evidence that the gene expression of monozygotic twins differ with increasing age and the more their lifestyles vary. In summary, environmental factors, such as physical exercise, interact with the epigenome contributing to phenotypical and performance differences of the same genome. Whether the sports science community should employ forms of genetic testing on this basis, raised multiple questions, including ethical questions for sports medicine in talent development.

\section{Ethical implications of genetic testing}

According to the Council of Europe Bioethics Convention and the US Genetic Information Non-discrimination Act, tests on gene predisposition are ethically, or legally, applicable only for strict health reasons and not for capacity evaluation or employment purposes [20]. Given the economic rewards and the prestige of professional sports, the use of genetic testing under the veil of health reasons and privacy protection might be underestimated. As a result, ethical standards should strictly prohibit the use of invasive genetic manipulation to improve performance in sport (McNamee, Müller, van Hilvoorde, \& Holm, 2009; WADA, 2018). On the other hand, interventions that are external and not invasive might be acceptable. This could include the creation of an environment that supports health, exercise selection, training programs, nutrition and regeneration for a performance-enhancing gene expression (Guilherme, Tritto, North, Lancha-Júnior, Artioli, 2014).

\section{Practical implications}

Since the environment also determines how the genotype is converted into the phenotype, genetics should be considered in the process of talent development in a dynamic, multiplicative and multidimensional manner (Simonton, 1999). In order control the environmental influences longitudinally, a panel study design should be chosen wherever possible. Based on existing evidence, the mindset that talent is innate, fixed and immutable can be refuted. In addition, the effort to recognize talents as early as possible (before puberty) and to commit to this decision is problematic. This "fixed-mindset" of epigenetics might hinder optimal talent development. According to the self-theory by Dweck (2013) individuals who believe in their talent, or even that their gene expression can be developed through hard work and input from others have a "growth mindset". They tend to achieve more than those with a more "fixed mindset" (those who believe their talents are innate). There is evidence that gene expression is not fixed, but adaptable and that gene expression can be positively influenced by a constant effort to improve. This is not only important for researchers, but also for coaches. Both of whom should adapt to such knowledge to optimize the athlete's environment.

\section{Conclusion}

Research in the epigenetics has provided evidence that talent consistsof interactions between genes and the environment. Therefore epigenetics builds the bridge between the former nature versus nurture debate. In the future, epigenetic characteristics and their potential influence on athletic performance should be considered, researched and validated with the help of well-controlled model systems to transfer them into the training environment. In doing so, the sport science commu- 
nity will face the difficult task of defining ethical standards that prohibit gene manipulation, but will allow the creation of an environment that produce performance-enhancing gene expression. This requires researchers from the fields of genetics, epigenetics, sports science and stakeholders of sport federations to work together in a multidisciplinary way.

\section{Acknowledgements}

I would like to express my gratitude for the revision and helpful comments by Marie Javet, Jörg Fuchslocher, Dennis-Peter Born and Stephen Cobley.

\section{Funding}

The authors have no funding or support to report.

\section{Competing Interests}

The authors have declared that no competing interests exist.

\section{Data Availability Statement}

All relevant data are within the paper.

\section{References}

Cobley, S., Till, K. (2017). Longitudinal studies of athlete development: Their importance, methods and future considerations. In Joseph Baker, Stephen Cobley, Jorg Schorer, Nick Wattie (Eds.), Routledge Handbook of Talent Identification and Development in Sport, (pp. 250-268). Abingdon: Routledge.

Coutinho, P., Mesquita, I., Fonseca, A. M., \& De Martin-Silva, L. (2014). Patterns of sport participation in Portuguese volleyball players according to expertise level and gender. International Journal of Sports Science \& Coaching, 9(4), 579-592.

Dweck, C. S. (2013). Self-theories: Their role in motivation, personality, and development: Psychology press.

Egger, G., Liang, G., Aparicio, A., \& Jones, P. A. (2004). Epigenetics in human disease and prospects for epigenetic therapy. Nature, 429(6990), 457.

Ehlert, T., Simon, P., \& Moser, D. A. (2013). Epigenetics in sports. Sports Medicine, 43(2), 93-110.

Feinberg, A. P. (2018). The key role of epigenetics in human disease prevention and mitigation. New England Journal of Medicine, 378(14), 1323-1334.

Fraga, M. F., Ballestar, E., Paz, M. F., Ropero, S., Setien, F., Ballestar, M. L., ... Benitez, J. (2005). Epigenetic differences arise during the lifetime of monozygotic twins. Proceedings of the
National Academy of Sciences, 102(30), 10604-10609.

Gerstein, M. B., Bruce, C., Rozowsky, J. S., Zheng, D., Du, J., Korbel, J. O., ... Snyder, M. (2007). What is a gene, post-ENCODE? History and updated definition. Genome Research, 17(6), 669-681.

Guilherme, JP., Tritto, AC., North, KN., Lancha-Júnior, AH., Artioli, GG. (2014). Genetics and sport performance: current challenges and directions to the future. Rev Bras Educação Fís Esporte; 28(1):177-193.

Haugaasen, M., Toering, T., \& Jordet, G. (2014). From childhood to senior professional football: A multi-level approach to elite youth football players' engagement in football-specific activities. Psychology of sport and exercise, 15(4), 336-344.

Howe, M. J. A., Davidson, J. W. \& Sloboda, J. A. (1998). Innate talents: Reality or myth?

Behavioral and Brain Sciences, 21, 399-422.

McNamee, M. J., Müller, A., van Hilvoorde, I., \& Holm, S. (2009). Genetic testing and sports medicine ethics. Sports Medicine, 39(5), 339-344.

Rees, T., Hardy, L., Güllich, A., Abernethy, B., Côté, J., Woodman, T., ... Warr, C. (2016). The Great British Medalists Project: A Review of Current Knowledge on the Development of the World's Best Sporting Talent. Sports Medicine, 1-18.

Rupert, J. L. (2003). The search for genotypes that underlie human performance phenotypes. Comparative Biochemistry and Physiology Part A: Molecular \& Integrative Physiology, 136(1), 191-203.

Schmitt-Ney, M., Happ, B., Ball, R. K., \& Groner, B. (1992). Developmental and environmental regulation of a mammary gland-specific nuclear factor essential for transcription of the gene encoding beta-casein. Proceedings of the National Academy of Sciences, 89(7), 3130-3134.

Sharp, N. C. (2008). The human genome and sport, including epigenetics and athleticogenomics: a brief look at a rapidly changing field. Journal of Sports Sciences, 26(11), 1127-1133.

Simonton, D. K. (1999). Talent and its development: An emergenic and epigenetic model. Psychological Review, 106(3), 435.

Vaeyens, R., Lenoir, M., Williams, A. M., \& Philippaerts, R. (2008). Talent identification and development programmes in sport: Current models and future directions. Sports Medicine, 38(9), 703-714.

Venter, J. C., Adams, M. D., Myers, E. W., Li, P. W., Mural, R. J., Sutton, G. G., ... Holt, R. A. (2001). The sequence of the human genome. Science, 291(5507), 1304-1351.

World Anti-doping Agency (WADA) Prohibited List (2018). https://www.wada-ama.org/sites/default/files/prohibited_ list_2018_en.pdf. Accessed December 03, 2018. 


\title{
Innate talent in sport: from theoretical concept to complex reality - comment on Baker \& Wattie
}

\author{
Nikki Rommers ${ }^{1,2,3, *}$ \& Roland Rössler ${ }^{4,5}$ \\ 1 Department of Movement and Sports Sciences, Vrije Universiteit Brussel, Brussels, Belgium \\ 2 Department of Movement and Sports Sciences, Ghent University, Ghent, Belgium \\ 3 Research Foundation Flanders (FWO), Belgium \\ 4 Amsterdam Collaboration on Health and Safety in Sports, Amsterdam UMC, Vrije Universiteit, \\ Amsterdam, Department of Public and Occupational Health, Amsterdam Movement Sciences \\ 5 Department of Sport, Exercise, and Health, University of Basel, Basel, Switzerland \\ * Corresponding author: Pleinlaan 2, 1050 Brussels, Belgium \\ Tel: +32-2-6292755 \\ E-Mail: nikki.rommers@vub.be
}

\section{COMMENTARY}

\section{Article History:}

Submitted $17^{\text {th }}$ December 2018

Accepted 21 th December 2018

Published $7^{\text {th }}$ May 2019

\section{Handling Editor:}

Lisa Steidl-Müller

University of Innsbruck, Austria

Editor-in-Chief:

Martin Kopp

University of Innsbruck, Austria

\section{ABSTRACT}

Over the last 20 years, the concept of innate talent has been discussed in the literature, and different factors have been associated with talent in different sports. However, it should be noted that talent identification is sport-, or even position-specific, and no 'one size fits all' consensus can be established. Specific talent profiles should be developed, acknowledging the multidimensionality of talent by taking physical, physiological, cognitive, psychological, and motivational factors into account. These profiles should also be age-specific and adjusted for covariates such as maturational timing and training history. To make a step forward in talent identification, we should not only move ahead in identifying innate talent, but also acknowledge the multifaceted and dynamic nature of talent. Therefore, we recommend researchers and practitioners to start approaching talent as a multidimensional, complex system.

Keywords:

Talent identification - youth sport - complexity

Citation:

Rommers, N. \& Rössler, R. (2019): Innate talent in sport: from theoretical concept to complex reality - comment on Baker \& Wattie Current Issues in Sport Science, 4:106. doi: 10.15203/CISS_2019.106

This is a commentary on a CISS report article authored by Baker, J. \& Wattie, N. (2018). Innate talent in sport: Separating myth from reality. Current Issues in Sport Science, 3:006. doi: 10.15203/CISS_2018.006

\section{Introduction}

Baker and Wattie (2018) revisit in their review the concept of innate talent and relate it to the domain of sport. It is an important piece of work explaining the concept of innate talent and the potential relevance of this concept in the field of sport. It gives great insights in the current knowledge and practice within the field of talent identification in sport. The authors conclude that "any understanding of innate talent cannot be divorced from the necessity to understand the complete eco- logy of the developmental environment" (Baker \& Wattie, 2018). They emphasize the point that any talent identification factor needs to be measurable and needs to have an association with future performance in order to be of relevance to the field. Therefore, at this moment, it is very hard to determine whether identification of innate talent is possible, and whether it is of any relevance in a sports context. Our commentary will elaborate on the concept of talent in sport and the challenges of identifying talented youth athletes in the complex reality. 


\section{Talent identification in youth sport}

Talent identification starts with the difficult task to define 'talent'. Two distinct concepts are discussed in the field of sport science: giftedness and talent. Giftedness denotes the potential of children for becoming professional adult athletes (Gagné, 1995). Talent is a concept that is hard to define, but it generally refers to mastery of certain skills (Gagné, 1995). The term talent is often used when talking about gifted young athletes, who might have the potential to develop into future professionals and high performers (later in life). Throughout this commentary, we will use the term gifted to describe athletes who have the potential to make it into professional athletes, while the term 'talent' refers to the best performing athletes at that current moment.

The review of Baker and Wattie (2018) focusses on genetic predisposition with regards to talent. We are looking for the extremes in a continuum of a normally distributed variable in the population. To enable the development of gifted young athletes and provide them with all external support to lead them to the top, we want to identify these extreme values early enough, and label these individuals as gifted (Vaeyens, Lenoir, Williams, \& Philippaerts, 2008; Williams \& Reilly, 2000). However, when discussing genetic predisposition, we should not forget that an individual fulfilling the requirements for being 'gifted', will never succeed in a certain sport without starting to participate in the first place and then keep practicing (i.e. investing time) until reaching proficiency. Making it to the top normally requires a substantial amount of training and/or competition experience (Baker \& Young, 2014). This raises the question in which population we should look for our gifted athletes: should we look for certain characteristics in the general population of children (i.e. identification of extremes in the population), or can we assume that gifted athletes themselves will find their way to the sport in which they have the potential to excel (i.e. identification of the most gifted athletes in a specific sport)?

Current practice in talent identification focusses on athletes already involved in the sport. When searching for gifted athletes, the attention often moves to the currently best performing individuals. It is difficult to identify gifted athletes, as no clear standards are available. It is not easy to identify characteristics in young children that are important for top performance at adult level. Characteristics of gifted athletes are also very specific. Different sports (Pion et al., 2015), or even different playing positions within a team sport (Pion et al., 2018), require different abilities or at least a different combination of them. Therefore, a "one size fits all" consensus for talent identification in sports is not possible. Talent profiling should specifically target one sport, and one playing position. When such a specific profile is available, we should ask ourselves when to start identifying the potentially gifted athletes. In most sports, we see that it takes several years of committed training until the athlete could reach international level. In woman's gymnastics, where flexibility and strength-to-weight-ratio are key elements to performance, the optimum age for maximum performance is lower than for example in endurance sport where the cardiovascular system needs to be fully developed and trained which takes several years after puberty. Consequently, talents in gymnastics need to be identified earlier than in endurance sports.

Many characteristics sought after in the identification and detection of potentially talented athletes, such as motor performance, will only significantly develop during adolescence (Leyhr, Kelava, Raabe, \& Honer, 2018), and are biased by (relative) age, biological development, training level, and experience as well as training age at the moment of assessment (Leyhr et al., 2018; Lovell et al., 2015; Rommers et al., 2018; Vaeyens et al., 2006). Therefore, characteristics focused on in talent identification should be specific for a certain (biological) age in the first place. Furthermore, developmental variations, such as the maturational timing during adolescence, should be taken into account to make sure that young athletes are compared to athletes of the same physical and mental developmental stage (Meylan, Cronin, Oliver, \& Hughes, 2010).

The training experience is also a critical component to be considered when evaluating whether individuals can be considered as gifted athletes or talents (Helsen, Hodges, Winckel, \& Starkes, 2000). A margin in experience and training stimuli resulting in structural adaptations (e.g. muscles, cardio-vascular system) might make one individual more successful at a given point in time than another individual (Nottin et al., 2002), although the latter one might be more gifted. This training experience is often to be taken into account.

Apart from emphasizing relevant covariates such as maturational timing and training experience, the multidimensionality of the concept of 'giftedness' in general should be underpinned (Phillips, Davids, Renshaw, \& Portus, 2010). An example: elite cyclists show high VO2max values compared to the general population. Consequently, one might think of using VO2max tests to determine performance in road cyclists and to screen for talents. However, a higher VO2max value will not necessarily result in better race performance (Coyle et al., 1991). Therefore, a talent screening based on the $\mathrm{VO} 2 \mathrm{max}$ parameter (alone) might tell us who cannot make it to the world tour level (i.e. cyclists with values under a certain threshold) but not who will make it to the top. Many other factors are needed to eventually reach the top level. Apart from physical and physiological characteristics, also cognitive, psychological and motivational variables play a key role in the giftedness of an athlete. Not only the multidimensional characteristics at that specific moment, but also the expected learning curve, psychological readiness and motivation of the athlete and the people surrounding this athlete (Phillips et al., 2010).

So in general, we can conclude that talent identification is a much broader and more complex topic than innate talent. Even if we take all previously mentioned issues into account (looking in the general population, using multidimensional sport or position-specific talent profiles that vary with age, correct for covariates such as maturational timing, and the training history), we will still do not have the guarantee to identify the 
athletes that will make it to the top. This is not only because an athlete could drop out, due to some particular "inciting event" (e.g. an injury), or quit the sport in which he or she would have had the potential to excel, but often because of the complexity of talent identification.

\section{Future perspectives of talent identification}

Future research should move beyond the question of innate talent and the identification of individual factors, and focus on identifying the gifted athletes who have the potential to make it into future professionals. Hereby, the complex reality of giftedness should be acknowledged. Talent identification is a multifaceted, dynamic system looking at time varying factors that are interacting with each other. It is hard to draw a causal picture of potential pathways leading young gifted athletes towards expert proficiency in sports. There are many potential confounders and mediators in these pathways that should be taken into account. Therefore, in contrast with previous studies, we suggest to approach talent identification as a multidimensional, complex system. We might identify the elements composing the complex puzzle of what makes the gifted athlete. All these elements should be considered together and the causal pathways need to be studied if we want to identify young athletes with a high potential to reach expert level as adults.

\section{Funding}

The authors have no funding or support to report.

\section{Competing Interests}

The authors have declared that no competing interests exist.

\section{References}

Baker, J., \& Wattie, N. (2018). Innate talent in sport: Separating myth from reality. Current Issues in Sport Science (CISS).

Baker, J., \& Young, B. (2014). 20 years later: Deliberate practice and the development of expertise in sport. International Review of Sport and Exercise Psychology, 7(1), 135-157.

Coyle, E., Feltner, M., Kautz, S., Hamilton, M., Montain, S., Baylor, A., ... Petrek, G. (1991). Physiological and biomechanical factors associated with elite endurance cycling performance. Med Sci Sports Exerc, 23(1), 93-107.

Gagné, F. (1995). From giftedness to talent: A developmental model and its impact on the language of the field. Roeper Review, 18(2), 103-111.

Helsen, W., Hodges, N. J., Winckel, J. V., \& Starkes, J. L. (2000). The roles of talent, physical precocity and practice in the devel- opment of soccer expertise. J Sports Sci, 18(9), 727-736. doi: 10.1080/02640410050120104

Leyhr, D., Kelava, A., Raabe, J., \& Honer, O. (2018). Longitudinal motor performance development in early adolescence and its relationship to adult success: An 8-year prospective study of highly talented soccer players. PLoS One, 13(5), e0196324. doi: 10.1371/journal.pone.0196324

Lovell, R., Towlson, C., Parkin, G., Portas, M., Vaeyens, R., \& Cobley, S. (2015). Soccer Player Characteristics in English LowerLeague Development Programmes: The Relationships between Relative Age, Maturation, Anthropometry and Physical Fitness. PLoS One, 10(9), e0137238. doi: 10.1371/journal. pone.0137238

Meylan, C., Cronin, J., Oliver, J., \& Hughes, M. (2010). Talent Identification in Soccer: The Role of Maturity Status on Physical, Physiological and Technical Characteristics. International Journal of Sports Science \& Coaching, 5(4), 571-592. doi: 10.1260/1747-9541.5.4.571

Nottin, S., Vinet, A., Stecken, F., N'GUYEN, L. D., Ounissi, F., LECOQ, A. M., \& Obert, P. (2002). Central and peripheral cardiovascular adaptations to exercise in endurance-trained children. Acta physiologica scandinavica, 175(2), 85-92.

Phillips, E., Davids, K., Renshaw, I., \& Portus, M. (2010). Expert performance in sport and the dynamics of talent development. Sports Medicine, 40(4), 271-283.

Pion, J., Segers, V., Fransen, J., Debuyck, G., Deprez, D., Haerens, L., ... Lenoir, M. (2015). Generic anthropometric and performance characteristics among elite adolescent boys in nine different sports. Eur J Sport Sci, 15(5), 357-366. doi: 10.1080/17461391.2014.944875

Pion, J., Segers, V., Stautemas, J., Boone, J., Lenoir, M., \& Bourgois, J. (2018). Position-specific performance profiles, using predictive classification models in senior basketball. International Journal of Sports Science \& Coaching, 1747954118765054.

Rommers, N., Mostaert, M., Goossens, L., Vaeyens, R., Witvrouw, E., Lenoir, M., \& D'Hondt, E. (2018). Age and maturity related differences in motor coordination among male elite youth soccer players. I Sports Sci, 1-8. doi: 10.1080/02640414.2018.1488454

Vaeyens, R., Lenoir, M., Williams, A. M., \& Philippaerts, R. M. (2008). Talent identification and development programmes in sport : current models and future directions. Sports Med, 38(9), 703-714.

Vaeyens, R., Malina, R. M., Janssens, M., Van Renterghem, B., Bourgois, J., Vrijens, J., \& Philippaerts, R. M. (2006). A multidisciplinary selection model for youth soccer: the Ghent Youth Soccer Project. Br J Sports Med, 40(11), 928-934; discussion 934. doi: 10.1136/bjsm.2006.029652

Williams, A. M., \& Reilly, T. (2000). Talent identification and development in soccer. J Sports Sci, 18(9), 657-667. doi: $10.1080 / 02640410050120041$ 


\title{
Talent: A contestable, but not contested, concept?
}

\section{Response to commentaries}

\author{
Joseph Baker ${ }^{1} \&$ Nick Wattie ${ }^{1, *}$ \\ 1 Lifespan Health and Performance Laboratory, York University, Toronto, Canada \\ 2 Faculty of Health Sciences, Ontario Tech University, Oshawa, Canada \\ * Corresponding author: Faculty of Health Sciences, 2000 Simcoe Street North, Ontario Tech University, Oshawa, Canada \\ Tel: +1 9057218668 ext 2248 \\ E-Mail: nick.wattie@uoit.ca
}

\section{TA ARTICEL}

\section{Article History:}

Submitted $15^{\text {th }}$ May 2019

Accepted $15^{\text {st }}$ June 2019

Published $12^{\text {th }}$ November 2019

Handling Editor:

Lisa Steidl-Müller,

University of Innsbruck, Austria

Editor-in-Chief:

Martin Kopp

University of Innsbruck, Austria

\section{ABSTRACT}

Our target article on 'Innate talent' had two objectives, first to acknowledge the 20th anniversary of the seminal contribution by Howe, Davidson and Sloboda (1998) and second, to update this information as it relates to talent in the domain of sport. Many thanks to all the authors that took the time to provide commentaries on our review. Broadly, our target paper focused on 1) whether the concept of innate talent was reasonable and scientifically sound and 2) whether the concept of innate talent had any utility to those working at the coalface of sport science (e.g., coaches, scouts, etc.). All of the commentaries were complimentary to our review, which suggested continued interest in this area (although this was noted as surprising by Hambrick and Burgoyne). We have tried to respond to all of the interesting points raised by the commentaries, but this was not always possible. That said, we grouped our responses under general themes below. Our impression, based on the commentaries, is that innate talent is not a contested concept; in that there appears to be agreement (for the most part) that, 'this thing exists'. Rather, the concept of innate talent is contestable (Gallie, 1956); that is, there is debate about exactly what it is, the degree of its influence, and how useful the concept of innate talent is.

Keywords:

Talent - sport - nature nurture debate - expertise - athlete development

Citation:

Baker, J. \& Wattie, N. (2019). Talent: A contestable, but not contested, concept? Response to commentaries. Current Issues in Sport Science, 4:108. doi: 10.15203/CISS_2019.108.

Baker, J. \& Wattie, N. (2018). Innate talent in sport: Separating myth from reality. Current Issues in Sport Science, 3:006. doi: 10.15203/CISS_2018.006

\section{What is talent?}

One of the themes that emerged from multiple commentaries related to 'what talent is'. Some of the authors used a different set of nomenclature than we did, and multiple authors emphasized the need to conceptualize talent as the combination of genetic and environmental factors.

The purpose of our paper was certainly not to pit nature vs. nurture (as implied by the title of Hambrick and Burgoyne's commentary: "Beyond nature vs. nurture in expertise research").
Indeed, in our critique of Howe et al.'s Criteria 5, we state that predisposition and innate capacity (innate talent), combined with time and training, are necessary for attainment expert performance in sport. Moreover, in the opening paragraph of our section, the concept of innate talent is valid, we state that,

"the premise of innate talent as a concept does not have to rely on a dichotomized or deterministic conceptualization (i.e., that innate talent is the sole determinant of sport expertise), but rather, there may be evidence supporting varying degrees of innate talent, where talent exists on a continuum." 
We speculate that one of the casualties of arguing (necessarily) against nature-nurture dichotomies, may be a lack of detailed discussions about nature (innate talent) and nurture (practice/ the environment). This may be one of the reasons for the lack of agreement on an operational definition of 'talent' noted below. Have we, as a field, spent a disproportionate amount of time and effort arguing against false dichotomies, rather than striving for conceptual clarity about nature and nurture? We agree with Hambrick and Burgoyne that we should be far beyond nature vs. nurture dichotomies in expertise research, but we do not feel that the concept of innate talent is synonymous with this dichotomy. The concept of innate talent can exist alongside the view that expertise results from interactions between nature and nurture. As such, we need discussions about innate talent because at a basic level we still lack consensus on what talent is. The need for consensus and rigour is real. Despite theoretical and empirical limitations to our understanding of talent, as we note in our review, people, policies, and youth sport structures act in ways that are consistent with notions of 'innate' talent; the horse is out of the barn.

The challenge of achieving conceptual clarity is complicated by the fact that discussions of innate talent necessarily intersect with multiple disciplines. For example, Rommers and Rössler suggest that "Talent is a concept that is hard to define, but it generally refers to mastery of certain skills (Gagne, 1995). The term talent is often used when talking about gifted young athletes, who might have the potential to develop into future professionals and high performers (later in life)... we will use the term gifted to describe athletes who have the potential to make it into professional athletes, which the term 'talent' refers to the best performing athletes at that current moment." Here Rommers and Rössler seem to have simply substituted 'gifted' for 'talent', otherwise they seem in agreement that the concept of innate talent has utility.

Similarly, Davids and Araújo describe talent as process of "internal dynamics", specifically as "underlying tendencies, dispositions and capacities related to successful performance in specific domains which may signal future potential for individual functionality". Faber noted that any account of talent is dependent on the particular context (sport-specific and historical), and some degree of chance. Again, none of these authors disagree with our position regarding the validity of innate talent as a concept. However, they emphasize the need for better conceptual clarity about the properties of talent in sport, an issue we have explored elsewhere (Baker, Wattie, \& Schorer, 2019).

\section{Does the concept have real world utility?}

Another common theme in the commentaries concerned the real world value of this notion of talent. While we and the commentators mostly agree the concept is reasonable, that does not mean it is useful, at least as it is currently defined. On the one hand, we agree with Rommers and Rössler that most approaches to talent selection are inherently flawed because they do not recognize the enormous complexity involved in athlete development. This runs counter to the arguments put forth by Romann as well as Hambrick and Burgoyne regarding the obvious value of heritable qualities like aerobic capacity or proportion of fast versus slow twitch muscle fibres. It is important here to highlight that while heritability estimates (i.e., such as those highlighting the high heritability of physiological outcomes) are useful when understanding populations of athletes, these same estimates have very little utility at the individual level because a) genetically constrained factors are also affected by the environment (e.g... it is not possible to take an athlete's performance/function at a single point in time and partial out the role of training on this outcome), b) phenotypic outcomes are determined by numerous genes (e.g., thousands of genetic variants have been associated with height, Yang et al., 2010), and c) our ability to identify these genes is problematic at best (e.g., Webborn et al., 2015).

On the other hand, if we agree that talent is a reasonable concept, approaches to talent selection and development need to be updated to recognize this complexity and, more importantly, the limits of a linear, unidimensional focus. As Rommers and Rössler note, "a 'one size fits all' consensus for talent identification in sports is not possible". We agree and appreciate the non-linear dynamics approach advocated by Davids and Araujo. This is a strong framework for understanding and discussing the myriad factors dynamically interacting to affect athlete's performance and development. Their notion of 'adaptive flexibility' has important implications for coaching, training and the development of more appropriate models of longterm athlete development. However, key biological constraints (again, height being the most obvious) could ultimately limit the extent to which the developing athlete 'system' is able to be flexible in meeting performance and competition demands. Biological predispositions, however they manifest, will limit the range of opportunities available to each performer and unfortunately there is evidence that these constraints are getting harder to overcome. For instance, as sports have evolved, morphological factors have become more homogeneous (Norton \& Olds, 2001). In basketball players have gotten taller (especially centers), but more remarkably, they have gotten larger (i.e., increased stature). These changes will constrain the opportunities for individuals without predispositions for above average height and body size. This is not to suggest that we should select athletes based solely on morphological predictions; it takes more than size to be a successful athlete and sports are constantly evolving. Height is simply used here as the most obvious example of how genotype affects phenotype. However, it is important to move away from models of influence where talent is seen as 'innate, fixed and immutable' as suggested by Romann. Importantly, 'innate' does not mean fixed and immutable. This view of talent belongs in the past. Current research emphasizes genes influence our development in a way that is dynamic, based on our experiences and the opportunities provided by our environment. 


\section{Moving Forward}

A number of commentaries discussed issues related to how this field should move forward. One of the recurring topics related to the indicators or measures of talent. Faber noted that height is not always a predictor for all sports (pg. 3 "the validness of innate talent concerning anthropometric predisposition might not hold in all sports"), a point we completely agree with. Here, height was used as an example of a variable that is highly heritable and obviously important in some sports. Faber also proposes that importance of anthropometric characteristics like height may be overestimated "due to selection policies and the developmental system used in youth sport". While maturation-selection does indeed play an important role during youth sport, the leap to suggest that it is not a component of talent does not seem warranted. In fact, there is evidence that the importance of anthropometric characteristics (including factors other than height) has been increasing at elite levels of sport: In sports where height is valuable to performance, elite athletes have gotten taller over time (the inverse is also true). In sports where size is important, athletes have gotten larger. It is unlikely that this 'expanding universe of bodies' (see Norton \& Olds, 2001) is independent of the task constraints within sports at the highest level, and simply the result of temporary advantages in youth sport. We wonder which came first, the specialization of bodies at elite levels or the specialization of bodies at youth levels? We would think the former.

Hambrick and Burgoyne were surprised by our claim "with the exception of a few variables related to body size, no robust indicators of talent currently exist" and highlight the various physiological characteristics that have high heritability (e.g., aerobic capacity). If we know a certain variable is important (e.g., aerobic capacity, work ethic, etc.) then why can't we just select for this variable? As we've noted above, this view is too simplistic for several reasons. First, performance in most sports is the result of a complex interaction of variables (e.g., endurance sports require a high aerobic capacity and high levels of running economy, Shaw, Ingham, Atkinson, \& Follard, 2015) and talent selectors would not want to rely on a single variable to capture talent, even if reliable and valid indicators exist. Second, talent selection usually involves making selections between highly skilled athletes and slightly less skill athletes, which is profoundly more difficult than comparing athletes to non-athletes. In short, to us aerobic capacity is an excellent example to support our conclusion that the concept of talent is reasonable, but currently has limited practical utility.

Hambrick and Burgoyne also point to the fact that general intelligence $(' g$ ') is a reliable correlate of expertise in a range of other domains, and suggest that it may be a worth exploring with respect to sport expertise. This is interesting but prior work on cognitive function (i.e., general executive functions, working memory: see Buszard, Masters, \& Farrow, 2017; Farrow, Reid, Buszard, \& Kovalchik, 2018; Vestberg, Gustafson, Maurex, Ingvar, \& Petrovic, 2012) and performance in sport has been equivocal. We suspect that this may be due to the fact that talent is "a multidimensional construct that cannot be aggregated to a single score and is comprised from different combinations of different abilities" (p.4) There are different ways of being talented; talent reflects different permutations and combinations of characteristics, which also differ by sport: see Baker, Wattie, \& Schorer, 2019).

Given the complexity of talent as a concept, and of navigating potential indicators of talent, there are considerable challenges moving forward, for scientists and practitioners. The commentaries highlight the need to understand the different ways of being talented on a sport-specific basis. They also stress the need to better understand the ways environmental factors (including pedagogical approaches) interact with innate characteristics. The challenges are significant. We argue (as do some of the commentaries) that the gap between where we are and where we need to be, renders the concept of innate talent unusable. Certainly, practitioners, parents and athletes should be made aware of the fruitlessness of genetic testing for identifying and developing talented athletes; the scientific consensus on these products and services is that they should be avoided (Webborn et al., 2015).

Given the lack of consensus on what constitutes talent, or what the conceptual elements of talent are, there is also clearly a need to discuss these issues. Elsewhere, we have proposed some features of innate talent (Baker, Wattie, \& Schorer, 2019). However, these features, and those proposed by others, need to be reviewed, evaluated and revised. Much work needs to be done. Finally, we believe that there is real value in the targetarticle-commentary format for stimulating ideas and debates about important topics, and hope to see this format used more frequently going forward.

\section{Funding}

The authors have no funding or support to report.

\section{Competing Interests}

The authors have declared that no competing interests exist.

\section{Data Availability Statement}

All relevant data are within the paper.

\section{References}

Baker, J., Wattie, N., \& Schorer, J. (2019). A proposed conceptualization of talent in sport: The first step in a long and winding road. Psychology of Sport \& Exercise, 43, 27-33. 
Buszard, T., Masters, R.S.W., \& Farrow, D. (2017). The generalizability of working-memory capacity in the sport domain. Current Opinion in Psychology, 16, 54-57.

Farrow, D., Reid, M., Buszard, T., \& Kovalchik, S. (2018). Charting the development of sport expertise: Challenges and opportunities. International Review of Sport and Exercise Psychology, 11, 238-257.

Gallie, W.B. (1956). Essentially contested concepts. Proceedings of the Aristotelian Society, 56, 167-198.

Norton, K. \& Olds, T. (2001). Morphological evolution of athletes over the $20^{\text {th }}$ century. Sports Medicine, 31, 763-783

Shaw, A.J., Ingham, S.A., Atkinson, G., \& Follard,J.P. (2015). The correlation between running economy and maximal oxygen uptake: Cross-sectional and longitudinal relationships in highly trained distance runners. PLOS ONE, 10, e0123101

Vestberg, T., Gustafson, R., Maurex, L., Ingvar, M., \& Petrovic, P. (2012). Executive functions predict the success of top soccer players. PLoS ONE, 7, e34731.

Webborn, N., Williams, A., McNamee, M., Bouchard, C., Pitsiladis, Y., Ahmetov, I., ... \& Dijkstra, P. (2015). Direct-to-consumer genetic testing for predicting sports performance and talent identification: Consensus statement. British Journal of Sports Medicine, 49(23), 1486-1491.

Yang, J., Benyamin, B., McEvoy, B. P., Gordon, S., Henders, A. K., et al. (2010). Common SNPs explain large proportion of the heritability for human height. Nature Genetics, 42, 565-569. 